\title{
The Coronavirus Surface Glycoprotein
}

\author{
David Cavanagh
}

\section{PHYSICOCHEMICAL PROPERTIES}

\section{A. Electron Microscope Observations}

Coronaviruses are frequently claimed to have a characteristic morphology, including the possession of a "club-shaped" surface projection or spike (S) glycoprotein. However, in common with other aspects of the coronaviruses, the group exhibits variation with respect to the shape, size, and distribution of the S protein on the virion surface. Davies and Macnaughton (1979) described the spikes of infectious bronchitis virus (IBV) and human coronavirus (HCV) 229E as being "tear-drop" shaped and widely spaced, whereas those of murine hepatitis virus (MHV) type 3 were mostly "cone-shaped" and closely spaced, although in some MHV-3 preparations the spikes were more bulbous. Dimensions of $S$ vary not only among the coronaviruses but also depending on the staining procedure; following potassium phosphotungstate staining all three viruses had spikes approximately $20 \mathrm{~nm}$ long and $10 \mathrm{~nm}$ wide at the bulbous end, except for the cone-shaped spikes of MHV, which had a diameter of only $5 \mathrm{~nm}$ (Davies and Macnaughton, 1979). The entire S protein has been observed after solubilization and purification (Sturman et al., 1980; Cavanagh, 1983c). The nonenvelope-associated S1 subunit of the IBV S protein can become detached from the virion (Stern and Sefton, 1982a; Cavanagh and Davis, 1986).

DAVID CAVANAGH - Institute for Animal Health, Division of Molecular Biology, Compton Laboratory, Compton, Newbury, Berkshire RG20 7NN, England.

The Coronaviridae, edited by Stuart G. Siddell, Plenum Press, New York, 1995. 


\section{B. Sedimentation Characteristics}

Purification of the S protein of MHV, IBV, HCV strain 229E, bovine coronavirus (BCV), and porcine hemagglutinating encephalomyelitis virus (HEV) has been achieved using a combination of nonionic detergent and sucrose gradient centrifugation (Sturman et al., 1980; Hasony and Macnaughton, 1981; Cavanagh, 1983b; Schultze et al., 1990, 1991). When milligram quantities of IBV were used, it was necessary to dissociate and sediment the virus proteins in the presence of $1 \mathrm{M} \mathrm{NaCl}$; otherwise the $\mathrm{M}$ protein cosedimented with S /Cavanagh, 1983b). Spike has also been purified by affinity chromatography (Mockett, 1985; Daniel and Talbot, 1990). Sedimentation studies have been variously interpreted as indicating that $\mathrm{S}$ from virions is a homodimer or homotrimer (IBV: Cavanagh, 1983c), homodimer (MHV: Vennema et al., 1990b), or homotrimer (TGEV: Delmas and Laude, 1990).

\section{Electrophoretic Analysis}

It cannot be said that the $S$ protein, of the coronaviruses as a group, exhibits characteristic migration in sodium dodecyl sulfate-polyacrylamide gel electrophoresis (SDS-PAGE). The apparent molecular weight of uncleaved $S$ is in the range 170-220,000 $\mathrm{Da}$, depending on the virus. The extent of cleavage into amino-(N)terminal S1 and carboxy-(C)terminal S2 glycopolypeptides depends on the virus type, virus strain, and cell type used, and ranges from 0 to $100 \%$. The two cleavage products also vary in molecular weight, from 84 to 135,000 , and may be separated or comigrate in polyacrylamide gels. Examples of electrophoretic analysis include BCV (Hogue et al., 1984; Deregt et al., 1987; Cyr-Coats et al., 1988; Vautherot et al., 1992a), MHV-JHM (Siddell, 1982), MHV-A59 (Frana et al., 1985), HCV-OC43 (Hogue et al., 1984), HEV (Callebaut and Pensaert, 1980), IBV (Cavanagh et al., 1986a-c), turkey coronavirus (TCV) (Dea et al., 1989a), canine coronavirus (CCV), and porcine transmissible gastroenteritis virus (TGEV) (Garwes and Reynolds, 1981), and porcine epidemic diarrhea virus (PEDV) (Egberink et al., 1988). Additional references are to be found in the review by Siddell et al. (1983). S2 of IBV may aggregate (Stern and Sefton, 1982a) and stain poorly with Coomassie Brilliant Blue (Cavanagh, 1983b), while others have reported high-molecular-weight forms of $S$ that are irregularly obtained (e.g., Hogue et al., 1984). Care must be exercised, therefore, in the interpretation of polyacrylamide gel polypeptide profiles of coronaviruses that have not been extensively studied.

\section{PRIMARY STRUCTURE}

\section{A. Overall Features}

The $\mathrm{S}$ protein is a large glycoprotein that possesses an overall hydrophobic hydropathicity profile, a N-terminal signal sequence that is absent from the 
mature protein, a C-terminal hydrophilic sequence preceded by a membranespanning domain, and a large number (up to 35 ) of potential N-linked glycosylation sites, most of which appear to be occupied by glycans (Fig. 1). The entire $S$ protein gene has been sequenced for many strains of IBV (Binns et al., 1985, 1986; Niesters et al., 1986; Sutou et al., 1988; Jordi et al., 1989; Kusters et al., 1989a, 1990; Koch and Kant, 1990b; Cavanagh et al., 1992b; Jia et al., 1993a,b), TGEV (Jacobs et al., 1987; Rasschaert and Laude, 1987; Britton and Page, 1990; Wesley, 1990), the TGEV variant porcine respiratory coronavirus (PRCV) (Rasschaert et al., 1990; Britton et al., 1991; Wesley et al., 1991), the feline coronaviruses feline infectious peritonitis virus (FIPV) (de Groot et al., 1987a) and feline enteric coronavirus (FECV) (Wesseling et al., 1994), HCV-229E (Raabe et al., 1990), CCV (Horsburgh et al., 1992; Wesseling et al., 1994), PEDV (Duarte and Laude, 1994), several strains of MHV (Luytjes et al., 1987; Schmidt et al., 1987; Parker et al., 1989; Gallagher et al., 1990a,b; La Monica et al., 1991; Taguchi et al., 1992), BCV (Abraham et al., 1990; Boireau et al., 1990; Parker et al., 1990; Zhang et al., 1991), and HCV-OC43 (Künkel and Herrler, 1993; Mounir and Talbot, 1993).

There is great variation among the coronaviruses with respect to the size of the S polypeptide. Currently the shortest $S$ protein known is that of IBV, with approximately 1160 amino acids, while FIPV has the longest protein of 1452 amino acids (Fig. 1). The S protein of some, but not all, of the coronaviruses is cleaved to produce the $\mathrm{N}$-terminal S1 and C-terminal S2 glycopolypeptides.

\section{B. Specific Features}

\section{Glycosylation, Transport, and Maturation}

Another common feature of the spike glycoprotein of coronaviruses is the high degree of glycosylation, the number of potential glycosylation sites ranging from 21 (MHV) to 35 (FIPV) (Fig. 1) (see Section II.A for references). Both S1 and S2 are glycosylated, e.g., IBV-Beaudette has 16 and 12 potential glycosylation sites in S1 and S2, respectively. Comparison of the molecular weights after removal of the glycans and by comparison of the deduced molecular weight of the nascent polypeptide, obtained by sequencing, with that obtained from SDSPAGE, indicates that most of these sites are occupied by glycans.

That the glycans, cotranslationally added, are of the N-linked /via asparagine residues) type has been shown by their susceptibility to endoglycosidase$\mathrm{H}$ (Stern and Sefton, 1982b; Cavanagh, 1983a) and tunicamycin (Holmes et al., 1981; Rottier et al., 1981; Stern and Sefton, 1982b; van Berlo et al., 1987; Dea et al., 1989a,b). Indeed, following replication in the presence of tunicamycin, which prevents the attachment of $\mathrm{N}$-linked glycans, virus particles lacking $\mathrm{S}$ protein are produced. Conversion of the initial high mannose or simple glycans to complex or hybrid molecules is a slow process, the half-life being one or several hours (Vennema et al., 1990b,c). The MHV S protein is formed initially as a glycosylated monomer of molecular weight 150,000 , which then oligomerizes slowly. The 150,000 glycopolypeptide is converted to a 180,000 form, 


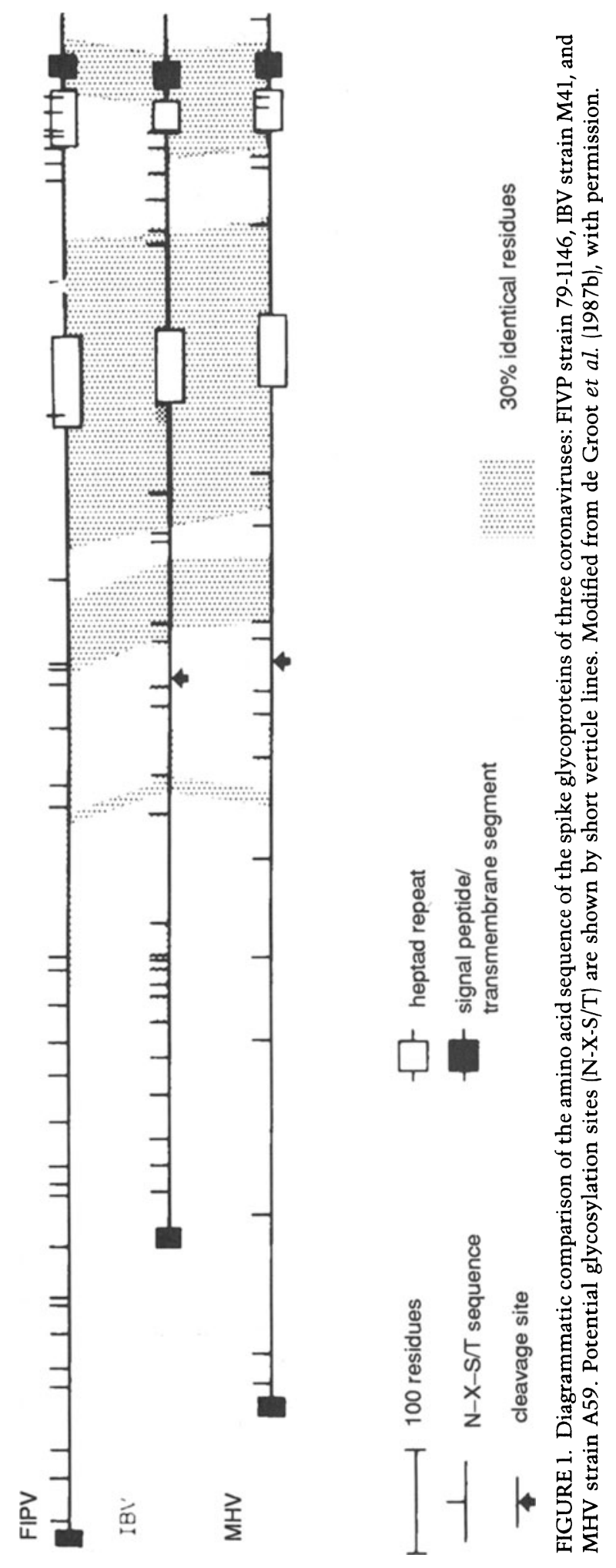


presumably involving modification of the simple glycans, after which cleavage into S1 and S2 occurs (Vennema et al., 1990b). In FIPV-infected cells, the oligomerization process was observed to be slower (half-time of 40-60 min) than that of the G glycoprotein and hemagglutinin of vesicular stomatitis virus (VSV) and influenza virus, respectively, but faster than that of Rous sarcoma virus envelope glycoprotein (Vennema et al., 1990b). The initial high mannose (simple) glycans become converted to complex ones, the half-time being about 1 $\mathrm{hr}$ in FIPV-infected cells (Vennema et al., 1990b,c). When S was expressed using vaccinia virus recombinants, the half-time of this process was approximately 3 hr. Coronavirus budding occurs at pre-Golgi membranes (see Opstelten et al., 1993, for references), the conversion of simple glycans to complex ones occurring after the budding. Thus the $S$ protein would appear to move faster through the Golgi apparatus when it is in virions than when it is not (Vennema et al., 1990c).

Similar observations had been made following infection of cells with TGEV (Delmas and Laude, 1990). Oligomers were formed before the simple glycans were converted to complex ones, the oligomerization being considered to have taken place not beyond the cis Golgi compartment. Many S monomers failed to oligomerize. When tunicamycin prevented glycosylation, oligomerization was prevented, indicating that the lack of glycans caused aberrant folding of the $S$ polypeptide.

Although S1 and S2 are not linked by disulfide bonds, there are many intrachain disulfide bonds. The ectodomain of the S protein of $\mathrm{MHV}$, for example, containes 42 cysteine residues. Opstelten et al. (1993) have studied the role of these disulfide bonds by incubating MHV-infected cells in the presence of dithiothreitol (DTT) to produce reducing conditions. The major conformational events involving disulfide bonds took about $20 \mathrm{~min}$. The process would appear to start on the nascent polypeptide. The DTT did not interfere with the functioning of the endoplasmic reticulum. Indeed, the membrane protein (M) was transported normally. Opstelten and colleagues (1993) state in their discussion that $M$ and $S$ form complexes almost immediately after synthesis, which accumulate at the site of budding (pre-Golgi membranes). Thus it may be the interaction of $S$ with $M$ that prevents $M$ progressing beyond the virus-budding site.

A small proportion of $S$ does progress to the cell surface following coronavirus infection (Laviada et al., 1990) and expression of $S$ involving vaccinia virus recombinants (Vennema et al., 1990c; Pulford and Britton, 1991; Oleszak et al., 1992; Kubo and Taguchi, 1993) and baculovirus (Yoo et al., 1990; Godet et al., 1991). The S1 subunit, expressed in the absence of S2 (which forms the membrane-anchoring stalk of S) was excreted. A truncated TGEV S protein, which lacked the carboxy-terminal 292 amino acids, was retained in the endoplasmic reticulum and did not progress to the cell surface (Pulford and Britton, 1991). However, a mutant TGEV spike gene that lacked 70 amino acids from the carboxy-terminus was excreted from cells after expression from a baculovirus recombinant (Godet et al., 1991). A mutant MHV S1 that contained the S2 transmembrane domain was transported to and retained at the cell surface, as was a mutant $\mathrm{S} 2$ to which had been added the $\mathrm{S} 1 \mathrm{~N}$-terminal signal peptide. When "normal" S1 and also S2 were transiently expressed in the same cells, S1 
was retained at the plasma membrane, suggesting that $\mathrm{S} 1$ and $\mathrm{S} 2$ had associated in a manner similar to that when the intact $S$ gene was expressed (Kubo and Taguchi, 1993).

\section{Cleavage of the Propolypeptide}

Although the S protein of some coronaviruses is cleavable by cell proteases, to yield S1 and S2, the extent to which this occurs varies, depending on the type and strain of virus and the host cell used. Cleaved spike has never been observed with two coronaviruses, TGEV and FIPV (Garwes and Pocock, 1975; Egberink et al., 1988). In the case of IBV strains from chicken embryos and chick kidney cells (Cavanagh and Davis, 1987; Stern and Sefton, 1982a), PEDV from infected pigs (Egberink et al., 1988), and TCV from human rectal carcinoma (HRT) cells (Dea et al., 1989a), all or almost all of the virion-associated spike was in the form of S1 and S2. Virions of IBV-Beaudette from Vero cells (Cavanagh et al., 1986b) and BCV-Mebus from HRT cells (Hogue et al., 1984; Cyr-Coats et al., 1988) had about $70 \%$ and $50 \%$ cleaved S, respectively. In contrast, almost none of the S of HCV-229E from human rhabdomyosarcoma cells (Schmidt and Kenny, 1982), MRC5 cells (Kemp et al., 1984), and human embryonic lung cells (Arpin and Talbot, 1990) and of HCV-OC43 (Hogue and Brian, 1986) was cleaved, although the latter studies have shown that $\mathrm{S}$ of $\mathrm{HCV}-\mathrm{OC} 43$ can be completely cleaved by trypsin. The role played by the cell type is well illustrated with MHV-A59, where the extent of $S$ cleavage varies from $0-100 \%$, depending on the host cell used (Frana et al., 1985).

Notwithstanding the requirement that cells have appropriate proteases with which to cleave $S$, there are features of some spike molecules that make them potentially more readily cleavable than the $S$ of other coronaviruses. Thus sequencing of the $S$ gene of many IBV strains has shown that the cleavage site is adjacent to a basic amino acid sequence, RRFRR, RRSRR, RRHRR, or GRHRR (Binns et al., 1985, 1986; Cavanagh et al., 1986b, 1988; Niesters et al., 1986; Kusters et al., 1989a). MHV strains JHM and A59 have basic connecting peptides comprising RRARR and RRAHR, respectively (Schmidt et al., 1987; Luytjes et al., 1987), and BCV has the sequence KRRSRR or KRRSVR at the corresponding location (Abraham et al., 1990; Boireau et al., 1990; Parker et al., 1990, Zhang et al., 1991). These basic sequences, which would be situated at the surface of the protein, would be expected to make the spike sensitive to those cell proteases that hydrolyze adjacent to basic residues. In the case of influenza A viruses those strains that have the hemagglutinin (HA) protein cleaved in many cell types have an HA1-HA2 connecting peptide containing several basic residues, whereas those isolates in which cleavage occurs in fewer cell types have only a single basic residue at the cleavage site (Bosch et al., 1981). In keeping with this observation, the S of TGEV and FIPV, which has not been observed in a cleaved form, and that of HCV-229E, which is hardly cleaved, does not have any pairs of basic residues in the region analogous to the cleavage site of IBV and MHV (Rasschaert and Laude, 1987; Jacobs et al., 1987; de Groot et al., 1987a; Raabe et al., 1990). The capacity of the S protein of HCV-OC43 to be cleaved by trypsin is in keeping with the presence of the sequence RRSR, which is a potential 
cleavage site (Künkel and Herrler, 1993; Mounir and Talbot, 1993). The requirement for cleavage of $\mathrm{S}$ for the fusion process is discussed in Section V.3.

\section{Structure of $\mathrm{S} 2$}

The observation that urea removed S1 but no other polypeptide from IBV led to the suggestion that $\mathrm{S}$ was anchored in the envelope by S2 /Cavanagh, 1983c). Support for this view was provided by comparison of $\mathrm{N}$-terminal and nucleotide sequencing data that showed that $S 2$ was generated by cleavage of the $S$ precursor and that near the carboxy-terminus of $S 2$ there was a 44 residue, strongly hydrophobic sequence suggestive of a membrane-spanning domain (Binns et al., 1985; Cavanagh et al., 1986b). Analysis of the deduced amino acid sequences of the spike protein of IBV, MHV, and FIPV (de Groot et al., 1987b), supported by Rasshaert and Laude's (1987) deductions based on TGEV data, has revealed the presence of two regions in S2 with a seven-residue periodicity, forming heptad repeats (Fig. 1). These are indicative of a coiled-coil structure. Sedimentation studies have indicated that $S$ is either a homodimer or homotrimer. The results of a cross-linking study have favored the latter (Delmas and Laude, 1990). Currently, therefore, the oligomeric spike protein is envisaged as being anchored by an $\alpha$-helical region near to the C-terminus of S2. Just beyond the outer membrane surface is the shorter (minor) repeat structure predicted to be an $\alpha$-helix of 5 (IBV and MHV) or $7 \mathrm{~nm}$ (FIPV). The major repeat indicates a helix of some 10 (IBV and MHV) or $13 \mathrm{~nm}$ (FIPV) or more, which would span more than half of S (Fig. 1) (de Groot et al., 1987b). Thus $S$ is envisaged as a multimeric protein, possibly a homotrimer, the narrow stalk of $S$ being a complex coiled-coil structure, somewhat analogous to the hemagglutinin trimer of influenza virus (Wilson et al., 1981). Just before the membrane-spanning domain of $S$ is the sequence KWP. Terminating 10 residues upstream of KWP is a leucine-zipper motif, the length of these varying from three to five heptad repeats (Britton, 1991).

S2 of IBV-M41 was susceptible to trypsin and other proteases, near its $\mathrm{C}$-terminus, at residues close to the outer membrane surface (Cavanagh et al., 1986a). The S1 subunit of IBV could be quantitatively released from S2 by treatment with urea (Cavanagh and Davis, 1986). Although urea did not have this effect on MHV-A59, incubation of MHV at $\mathrm{pH} 8.0$ and $37^{\circ} \mathrm{C}$ did result in the release of S1 (Sturman et al., 1990; Weismuller et al., 1990).

\section{Conservation of S2 among Coronaviruses}

Comparison of the amino acid sequences of the spike proteins from IBV, MHV, FIPV, and TGEV has shown that there is far greater sequence conservation within the C-terminal, S2 part of the molecule than in S1 (Schmidt et al., 1987; de Groot et al., 1987b; Rasschaert and Laude, 1987). Within S2 are regions exhibiting $30 \%$ identical residues (Fig. 1), while comparison of S2 of BCV strain F15 with that of MHV-A59 reveals about 70\% homology (Fig. 4) (Boireau et al., 1990 ). One notable feature, shared by the various coronaviruses, is that whereas the average cysteine content of $\mathrm{S}$ is about $3 \%$, that in the $\mathrm{C}$-terminal hydro- 
philic tail, which is probably within the lumen of the virus, is around $24 \%$. Some of these cysteine residues may be associated with fatty acid chains, known to be present on S2 of MHV (Schmidt, 1982; Sturman et al., 1985; van Berlo, 1987).

All the coronavirus $S$ genes analyzed encode an highly conserved eightresidue sequence Lys-Trp-Pro-Trp-Trp/Tyr-Val-Trp-Leu. The leucine-zipper motifs described in the previous section ends 10 residues before the Lys-Trp-Pro of this conserved sequence, the remainder of which probably forms the first part of the transmembrane domain (see Britton, 1991).

\section{Extensive Variation of $\mathrm{S} 1$ among Coronaviruses}

In contrast to the modest conservation of $\mathrm{S} 2$ within the coronavirus genus, S1 shows very little amino acid identity when some pairs of viruses are compared, e.g., IBV with TGEV (Rasschaert and Laude, 1987), IBV with MHV (Schmidt et al., 1987), and MHV with FIPV (de Groot et al., 1987b) (Fig. 1). Indeed, the extensive heterogeneity exhibited by $\mathrm{S} 1$ extends to strains within some coronavirus species, notably IBV. In recent years there has been extensive analysis of the antibody-inducing epitopes of some coronaviruses, the S1 subunit being the major inducer of virus-neutralizing (VN) antibodies in some coronaviruses, e.g., IBV and TGEV. Since sequence differences in S1 are responsible for many of the antigenic differences between coronaviruses it is appropriate to discuss sequence and antigenic variation in the same section (Section III).

\section{STRUCTURAL AND ANTIGENIC VARIATION OF S}

\section{A. S Protein Is a Major Inducer of Neutralizing Antibody}

All three surface glycoproteins of coronaviruses, S, M, and, when present, $\mathrm{HE}$, induce VN antibody (see Chapters 6 and 8, this volume, for M and HE, respectively). Although there are fewer $\mathrm{S}$ than $\mathrm{M}$ and $\mathrm{N}$ molecules in the virion (Cavanagh, 1981), the spike protein induces a good immune response following infection. That $\mathrm{S}$ induces VN antibody has been shown in three ways. First, by immunization with purified S protein of TGEV (Garwes et al., 1978/79), MHV (Hasony and Macnaughton, 1981), and IBV (Cavanagh et al., 1984). Second, by immunization with vectors expressing the S gene of IBV (Tomley et al., 1987), FIPV (de Groot et al., 1989), TGEV (Godet et al., 1991), and MHV (Daniel and Talbot, 1990; Wesseling et al., 1993). Third, by showing that many VN monoclonal antibodies (MAbs) bound to the S protein of MHV (references in subsequent sections).

\section{B. Location of Antigenic Sites}

A number of approaches have been used to locate antigenic sites on $S$, all involving the use of MAbs: competition enzyme-linked immunosorbent assay 
(ELISAs); production of polypeptides or peptides by proteolysis of $S$, prokaryotic expression vector or synthetically; and sequencing of MAb-resistant variants. No simple picture has emerged for the genus as a whole, except that $\mathrm{S} 1$ has more VN epitopes than S2 in some species.

Earlier, polyclonal antibody analyses (for references, see Spaan et al., 1990) indicated that each coronavirus could be placed into one of four antigenic groups. Combining more recent biochemical, sequence, and MAb analyses would suggest three groups. In one group would be TGEV, FIPV, CCV, HCV-229E, and PEDV. A second group would contain MHV, BCV, HCV-OC43, and TCV, while IBV would constitute the sole member of the third group /Chapter 1, this volume). It is instructive to compare the $S$ protein of coronavirus species within these groups. The $S$ protein differences observed among species within a group may play a role in host range and tissue specificity and certainly do so with respect to antigenic differences of practical importance.

\section{TGEV, FIPV, CCV, HCV-229E, and PEDV}

Four or five major antigenic domains were detected on the $S$ protein of TGEV using competition assays with MAbs (Delmas et al., 1986; Jimenez et al., 1986; Correa et al., 1988; Simkins et al., 1989; Enjuanes et al., 1990). Subsequently, extensive analysis of the binding of MAbs to proteolytic fragments of $S$ (Correa et al., 1990; Delmas et al., 1990a,b; Enjuanes et al., 1990), to S polypeptides generated in Escherichia coli (Enjuanes et al., 1990; Delmas et al., 1990a,b), to synthetic peptides (Posthumus et al., 1990a,b; Gebauer et al., 1991), and sequencing of MAb-resistant (MAR) mutants (Delmas et al., 1990a,b; Enjuanes et al., 1990; Gebauer et al., 1991) has revealed that the antigenic makeup of $S$ is complex. In addition, some sites would appear to be composed of sequences that are linearly far apart, but which are brought into close proximity by the folding of the protein, with one sequence playing a more prominent role than the other.

The major research teams in this area have used different systems for naming antigenic domains (see Gebauer et al., 1991, for a comparison) and a common nomenclature, using Roman numerals, has been proposed (Posthumus et al., 1990a,b). I have used this nomenclature in Fig. 2 to show the approximate positions of the antigenic domains, taking into account data generated by all the approaches referenced above.

The Sl part of $S$ is the major inducer of antibodies and many of the anti-S1 MAbs were VN. The major VN epitopes are in region I and are highly conserved among TGEV isolates. This, and the great difficulty experienced in obtaining MAR mutants to site I MAbs, has led to the conclusion that this region has an important function. Competition between MAbs and antibodies in sera raised following vaccination of pigs with TGEV confirmed the immunodominant nature of site A, in particular subsite antibody (Diego et al., 1992). Sites II and IV are also associated with VN epitopes. Site III is exposed on denatured but not native S. Differentiation among strains of TGEV has been achieved by MAbs directed against epitopes at sites II, III, and IV (Welch and Saif, 1988; Sanchez et al., 1990). Some epitopes may be formed by residues contributed from sites I and II (Correa et al., 1990; Delmas et al., 1990a,b), while residues in S2 (1176-1184) 


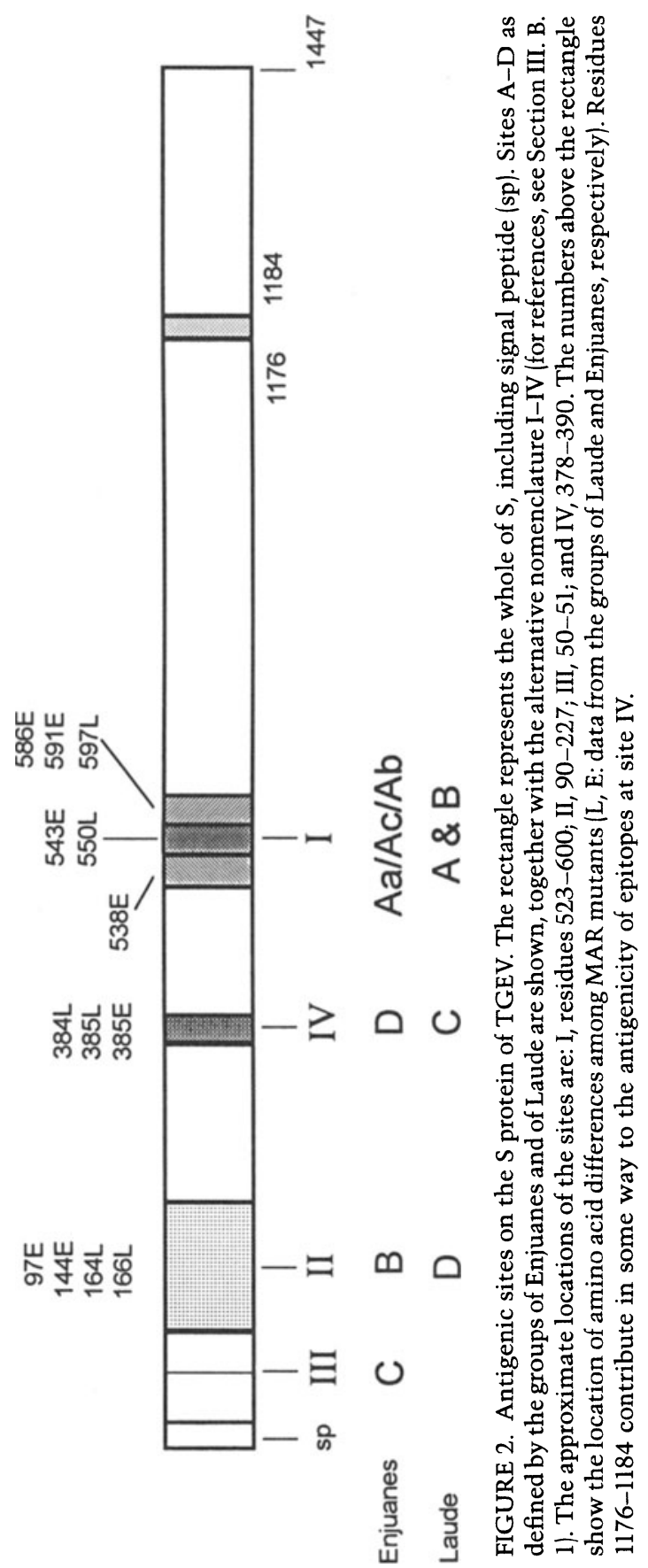


contribute in some way to the antigenicity of epitopes at site IV (Posthumus et al., 1990a,b, 1991).

There were differences among the sites with respect to the influence of glycans. The binding of MAbs to site IV was little affected by the absence of glycans on S, whereas nonglycosylated/deglycosylated S did not bind site I and II MAbs, and site III was perhaps an intermediate case (Gebauer et al., 1991; Delmas and Laude, 1991).

A very interesting variant of TGEV of economic importance was isolated in Europe in the mid-1980s (see Chapter 16, this volume). This variant was named porcine respiratory coronavirus because it replicated mainly in the respiratory tract of pigs and very little in the alimentary tract. Hence, it did not cause the enteric disease so characteristic of classical TGEV. Sequencing revealed mutations in gene 3 of PRCV, leading to loss of the first open reading frame, plus a large deletion of 672-681 nucleotides from near the beginning of the $S$ gene (Rasschaert et al., 1990; Britton et al., 1991; Wesley et al., 1991) (Fig. 3). Thus PRCV lacks antigenic sites II and III, and MAbs to these sites can be used to differentiate PRCV from TGEV (Garwes et al., 1988; Callebaut et al., 1988; Enjuanes et al., 1990; Simkins et al., 1992). The remainder of S of PRCV and TGEV have $98 \%$ identity and, correspondingly, have site I and IV epitopes in common (Sanchez et al., 1990).

The S proteins of TGEV and FIPV are almost identical in length, and for residues $275-1447$ there is $94 \%$ identity and some common site I and IV epitopes, including some that are $\mathrm{VN}$ and that mediate antibody-dependent enhancement of FIPV infectivity (see Chapter 14, this volume). In contrast, the first 274 residues have only $30 \%$ identity, and no common site II and III epitopes have been detected (Fig. 3) (Jacobs et al., 1987; Sanchez et al., 1990).

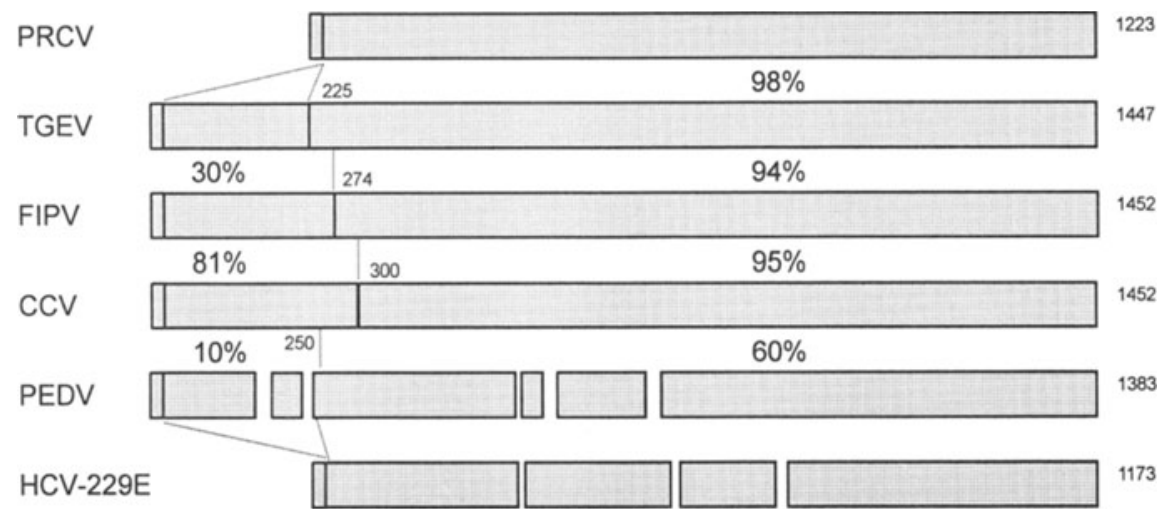

FIGURE 3. Amino acid sequence differences among the $S$ proteins of members of the TGEV group of coronaviruses. The diagram shows the much greater variation among the amino-terminal 225300 residues than among the remainder. The gaps between rectangles representing S of PEDV and HCV-229E show the approximate size and position of the largest deletions only. HCV-229E and the PRCV variant of TGEV lack the first 225 or so residues of the other species. The amino-terminal signal peptide is indicated by the lighter shading. 
Feline coronaviruses could be divided into two antigenic groups on the basis of binding of anti-S MAbs (Fiscus and Teramoto, 1987a,b; Hohdatsu et al., 1991). A feline coronavirus that did not cause FIP (FECV) had $90 \%$ and $97 \%$ amino acid identity within residues 1-300 and 301-1452, respectively, of a FIPV isolate (Wesseling et al., 1994).

The CCV S protein is the same length as that of FIPV, and residues 300-1452 have $95 \%$ identity (Horsburgh et al., 1992; Wesseling et al., 1993) and some site I epitopes in common, including VN epitopes (Fig. 3) (Sanchez et al., 1990; Hohdatsu et al., 1991). When the first 300 residues are compared, the identity with FIPV is still high, at $81 \%$ (Wesseling et al., 1993); many isolates of one species, IBV, differ from each other by this amount in the first 300 or so residues (see Section III.A.3). None of the TGEV site II and III MAbs of Sanchez et al. (1990) bound to CCV, in keeping with the low (38\%) identity between the first 300 residues of these two viruses.

The sequence of several genes of another porcine coronavirus, PEDV, have been determined recently and have confirmed that this virus more closely resembles the TGEV group than the other coronavirus groups. Although somewhat shorter than that of TGEV, the 1383 residue PEDV S does include the $\mathrm{N}$-terminal region that corresponds to the beginning of the TGEV S protein and is absent from PRCV (Fig. 3) (Duarte and Laude, 1994). However, there is only about $10 \%$ identity in this region when compared with TGEV, CCV, and FIPV. Not surprisingly, none of 25 anti-TGEV spike protein MAbs bound to PEDV (Sanchez et al., 1990).

Finally, sequence analysis of $\mathrm{HCV}-229 \mathrm{E}$ has confirmed its relationship to the TGEV group, although, like PRCV, the 229E S protein lacks the first 225 or so amino acids (Fig. 3) (Raabe et al., 1990). The extent of identity of the 229E S protein to that of TGEV, FIPV, and CCV is similar to that exhibited by PEDV. Thus, the first 550 or so amino acids have about $38 \%$ identity, the C-terminal half being greater $(57 \%)$. In contrast, the identity with the first half of S of MHV and IBV is only $16-18 \%$ and for the second half $32-35 \%$ (Raabe et al., 1990). Once again, none of the TGEV anti-S MAbs of Sanchez et al. (1990) bound to the 229E S protein.

\section{MHV, BCV, HCV-OC43, HEV, and TCV}

Recent sequencing and MAb studies of these viruses have confirmed their much greater similarity to each other than to other coronaviruses. Comparison has revealed a hypervariable region within $\mathrm{S} 1$ that is associated with some of the antigenic differences not only between these virus species but also among strains of a given species (Fig. 4). This hypervariable region may also be associated with host range and tissue tropism, although this is speculation. Sequence data are not available for the $S$ protein of HEV and TCV but they are for the other members of this group; it is to these that the following discussion of sequence applies.

The lengths of the $S$ proteins are very similar, ranging from 1351/53 for HCV-OC43 to 1376 for MHV-4 (see Section II.A for references). The BCV S protein is most closely related to that of HCV-OC43 (91\% identity) and less so with MHV 
Amino acid sequence differences among the S proteins of the 'MHV' group

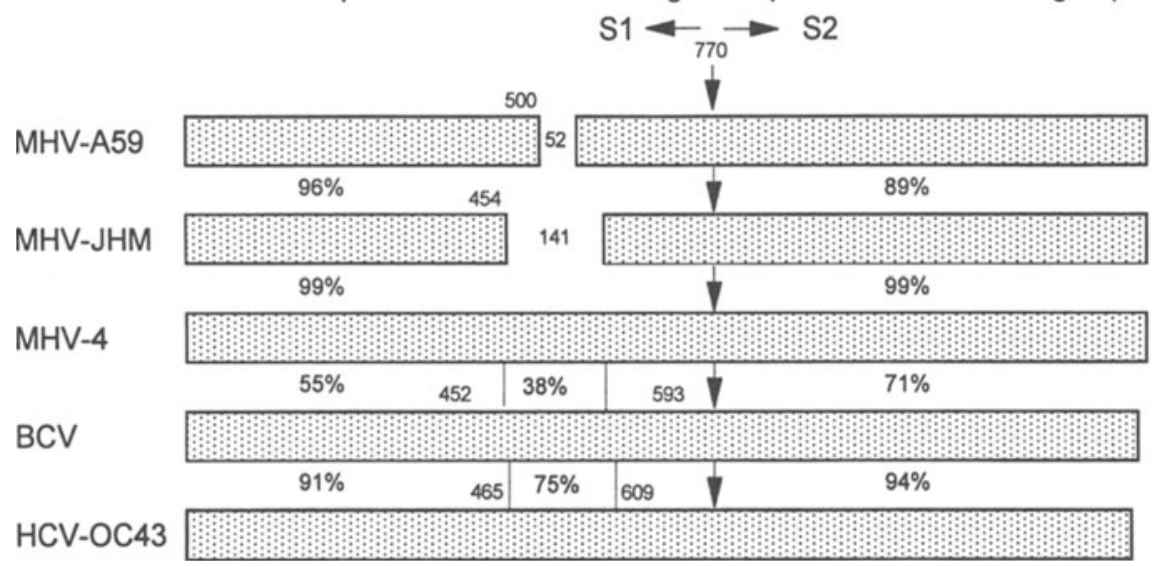

1324

1235

1376

1363

1353

FIGURE 4. Amino acid sequence differences among the S proteins of the MHV group of coronaviruses. The rectangles represent the whole spike protein, the numbering having been normalized with respect to that of the longest known MHV spike protein, belonging to strain MHV4. The arrow at position 770 marks the cleavage site between S1 and S2. The numbers in the gaps show the size of deletions compared with MHV4. The percentage differences shown for the pairs MHV-A59/MHVJHM and MHV-JHM/MHV-4 refer to comparisons of S1 and S2, excluding the deletions from S1. The percentage differences shown for the pairs MHV4/BCV and BCV/HCV-OC43 are for three areas, the middle one being the hypervariable region.

(about $60 \%$ ). HCV-OC43 also has approximately $60 \%$ identity to the $S$ protein of MHV. As observed with the other coronviruses, identity is greater in S2 (BCV:HCV, 95\%; BCV:MHV, 71\%) than in S1 (BCV:HCV, 88\%; BCV:MHV, 55\%).

The very high identity shown by BCV and HCV-OC43 is interrupted by a 135-residue sequence in S1 (residues 465-609 of HCV) in which the identity drops from $>90 \%$ to $75 \%$ (Fig. 4). The similarly situated residues of BCV (residues $452-593$ ) have $<40 \%$ identity with the corresponding region of MHV-4 compared with $>55 \%$ elsewhere in S (Fig. 4). Indeed, about half of the amino acid differences between S of MHV-4 and BCV occur within this region which accounts for only about $12 \%$ of $\mathrm{S}$. It is in this same region that strains of MHV differ dramatically from each other. Whereas most of the S1 of MHV strains has about $>90 \%$ identity, at this location there are deletions of a single stretch of amino acids as great as 159 residues (Taguchi et al., 1985; Luytjes et al., 1987; Morris et al., 1989; Parker et al., 1989; Taguchi and Fleming, 1989; Banner et al., 1990; Gallagher et al., 1990a,b; La Monica et al., 1991). It is likely that MHV-4 is a prototypic MHV strain, the commonly used A59 and JHM strains having been selected during passage in vitro.

The $S$ gene of six BCV strains, isolated in several countries in two continents, have been sequenced, revealing a very high conservation (98\% overall) (Zhang et al., 1991). Most of the differences (45-56 bases, 16 to 26 amino acids) were between virulent and avirulent strains, compared with only 6-14 base differences $(<10$ amino acids) among the four avirulent isolates. There were twofold more differences in S1 than S2, but the differences in S1 were not 
concentrated in one region. A BCV isolate from nasal swabs of a calf suffering from respiratory disorders had a $\mathrm{S}$ protein that had $98 \%$ amino acid identity with that of enteric BCV isolates (Zhang et al., 1994).

The first coronavirus to be extensively studied with respect to the location of its antigenic sites was MHV. A complex picture has emerged and might be summarized as follows. Following infection with MHV, epitopes formed by the S1 subunit induce antibodies with the highest VN activity. Most of these epitopes are conformational. In these respects $\mathrm{MHV}$ resembles $\mathrm{BCV}$, in addition to viruses of the TGEV group (Section III.B.1) and IBV (Section III.B.3). Some epitopes associated with the S2 subunit of MHV induce VN antibodies, but these have usually been of low titer. Several of these epitopes are continuous and have been mimicked by peptides. There is evidence from competition experiments with MAbs that some antigenic sites are formed or at least influenced by residues contributed by both S1 and S2.

Competition with MAbs revealed up to six epitope groups (Talbot et al., 1984; Wege et al., 1984; Talbot and Buchmeier, 1985) of which two (sites A and B) or three (sites A, B, and C) were associated with VN antibodies. Cell fusion was inhibited by site A MAbs. Direct evidence that the major VN epitopes reside on S1 has been derived from analysis of the binding of MAbs to S1 in the absence of S2. S1 expressed using a baculovirus was able to bind anti-S1 VN MAbs (Taguchi et al., 1990; Takase-Yoden et al., 1990). Using the cl-2 variant of MHV-JHM, the S1 and S2 glycopolypeptides of which can be distinguished in SDS-PAGE gels, Kubo et al. (1993) showed that of 15 MAbs raised against S, 14 immunoprecipitated $\mathrm{S} 1$ after this had been dissociated from S2 by urea and 2-mercaptoethanol. Nine of the 14 MAbs were VN, only one bound to S1 after boiling in the presence of SDS and DTT, and five of the VN MAbs failed to immunoprecipitate S1 after only mild denaturation (SDS at room temperature without DTT). Taken together, the MAb-binding studies of Takase-Yoden et al. (1990) and Kubo et al. (1993) show that some S1 residues form epitopes independently of S2 amino acids and that some of these epitopes are discontinuous in nature.

Neutralizing MAbs $11 \mathrm{~F}$ and 30B were induced by MHV-JHM sequences in bacterial fusion proteins and mapped to S1 residues 33-40 and 395-406, respectively (Fig. 5c) (Routledge et al., 1991). Competition experiments (Stuhler et al., 1991) using purified MHV-JHM revealed that MAb 30B competed with highly neutralizing, discontinuous epitope MAbs of the site A described by Wege et al. (1984). This indicates that residues around amino acid position 400 of the MHV S1 protein form at least part of site A (Wege et al., 1984) and play a major role in the induction of $\mathrm{VN}$ antibodies. This location is adjacent to a highly variable region of S1 (Fig. 5).

MAbs to sites B and C selected MHV-JHM variants that had large deletions in S1 (Talbot et al., 1984; Dalziel et al., 1986; Parker et al., 1989; Gallagher and Buchmeier, 1990; Gallagher et al., 1990; La Monica et al., 1991). This per se does not prove that the epitopes for these MAbs were located in this part of $\mathrm{Sl}_{\text {; }}$ the epitopes might have been situated elsewhere in S1 or in S2 and their configuration disrupted by the large deletion in S1. In this regard it is noteworthy that neither of the MAbs of Talbot et al. (1984) used to select the variants with the deletions in S1 could react with denatured S in Western blots, indicating that 
a $\mathrm{A} 59$

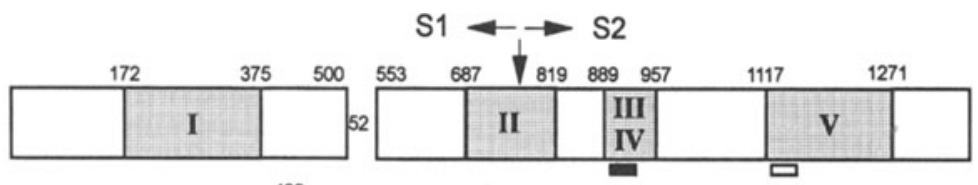

b JHM

tissue mutants

c JHM

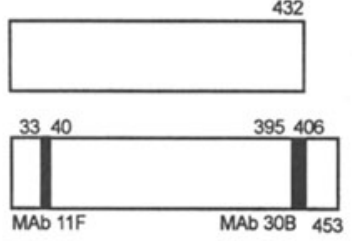

286

719

d MHV4

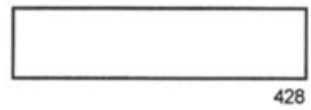

158

428
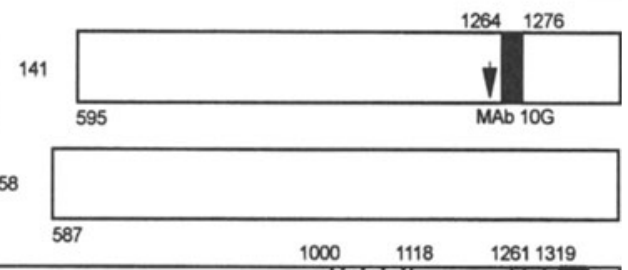

e MHV4

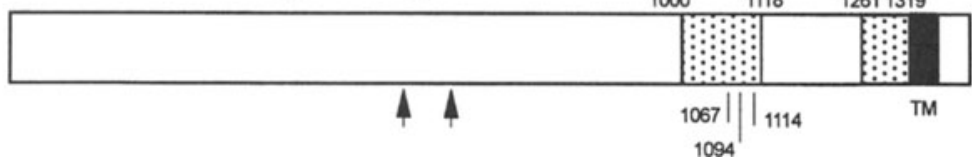

FIGURE 5. Antigenic and other sites within the S protein of strains of MHV. The amino acid numbering has been normalized with respect to that of the longest known MHV protein, that of MHV4. The numbers in the gaps show the size of deletions copared with MHV4. The arrow at position 770 marks the cleavage site between S1 and S2. (a) Shows the location of antigenic domains I-V identified by Daniel et al. (1993) using bacterially expressed fragments of S of MHV-A59. The small, filled rectangle represents the peptide of Luytjes et al. (1989) (residues 900-908), which bound the VN and anti-fusion Mab 19.2. The small, open rectangle represents the peptide of Talbot $e t$ al. (1988) (residues 1,135-1,144), which induced VN antibodies and protective immunity in mice. (b) S polypeptide of neurotropic variants of MHV-JHM isolated from the brain and spinal cord of JHMinfected rats (La Monica et al., 1991). (c) S of MHV-JHM showing three sites identified by the binding of bacterial expression products with VN MAbs $11 \mathrm{~F}$ and $30 \mathrm{~B}$ (MAb $11 \mathrm{~F}$ also inhibits fusion) and with VN and antifusion MAb 10G (Routlege et al., 1991). The arrow indicates the positions (1250, 1251, and 1257) of amino acid substitutions in MHV-JHM MAR mutants selected by MAb 11F (Grosse and Siddell, 1994). (d) S of a MAR mutant of MHV4 selected with MAb V4B11.3 (Parker et al., 1989). (e) S of MHV4 showing the heptad repeat regions (stippled) and membrane-spanning region (solid box). The locations are shown of three mutations present in mutants of MHV4 recovered from a persistently infected neural cell line, the mutants requiring a $\mathrm{pH}$ of 5.5-6.0 for membrane fusion (Gallagher et al., 1991). The arrows show the position of two point mutations present in a MAR mutant selected with MAb 7.2-V-1 (Wang et al., 1993).

the epitopes were of a discontinuous nature. Not all MAR mutants with mutations in S1 have deletions. For example, MAb 7.2-V-1 selected a MAR mutant of MHV-DL that had two point mutations, both in S1, at residues 588 and 650, the former within and the other very near the hypervariable region of MHV (Fig. 5e) (Wang et al., 1992). The hypervariable region is even larger than that indicated by comparison of MAR mutants, as La Monica et al. (1991) have shown with neurotopic variants of JHM isolated from the brain and spinal cord of JHMinfected Wistar Furth rats. These variants lacked 147 amino acids in addition to those already absent from JHM when compared with MHV4 (Fig. 5b).

A number of studies have shown that the situation is more complex than the foregoing account would imply. MAb 11F, which was induced by residues 
33-40 in a bacterially expressed product, was used to raise 10 MAR mutants. Sequencing of these showed that the single amino acid mutations were not located in residues $33-40$ but at positions 1109,1110 , and 1116 of the JHM S protein (equivalent to residues 1250, 1251, and 1257 of MHV4; Fig. 5c) (Grosse and Siddell, 1994). These mutations did not affect the binding of many other S1 and S2 MAbs, showing that the mutations had not caused extensive alterations to the structure of $\mathrm{S}$. This implies some specific interaction between amino acids in region 33-40 of S1 and those around residues 1109-1116 of S2.

Several other studies have shown the presence of epitopes on S2. A site A $\mathrm{MAb}$ that inhibited fusion reacted with an nine amino acid sequence, delineated using prokaryotic expression products and synthetic peptides, situated 131 residues downstream from the $\mathrm{N}$-terminus of S2 (Fig. 5a) (Luytjes et al., 1989). This region is particularly interesting because the MAb used, although neutralizing, could not select MAR mutants (Talbot and Buchmeier, 1985). Moreover, this site was highly conserved among MHV strains. Taken together, these observations suggest that this region of $S$ may have a vital function for the virus. The MAb directed against this peptide was able to protect mice from lethal infection (Koolen et al., 1990). The peptide has also been expressed as a chimeric protein and induced protection in mice (Brown et al., 1994).

Further involvement of S2 in the induction of VN antibodies has been shown by the finding that a decapeptide, corresponding to the sequence starting at residue 365 from the N-terminus of S2 of MHV-JHM, not only induced VN antibodies but also induced in mice some protection from a lethal challenge of MHV (Fig. 5a) (Talbot et al., 1988). Induction of a VN, and antimembrane fusion, MAb by MHV-JHM sequences in a bacterial fusion protein showed that S2 residues 1123-1137 of MHV-JHM (equivalent to residues 1264-1276 in the MHV4 strain) (Fig. 5c) induced antibodies with these properties (Routledge $e t$ a1., 1991). A VN MAb (2.2-V-1) selected a MAR mutant with a single amino acid substitution at residue 1113 in S2 of MHV-DL, a strain that has $>99 \%$ identity with MHV-JHM (Fig. 5) (Wang et al., 1992).

Recently Daniel et al. (1993) have investigated the antigenicity of bacterial fusion proteins containing overlapping fragments of the S protein of MHV-A59 (Luytjes et al., 1989). This strain lacks many of the residues of the hypervariable region described above (Fig. 5a). The products were examined by immunoblotting, using mostly MAbs that had previously been shown to bind to denatured $S$ (most likely binding to continuous epitopes) but also a few MAbs against discontinuous epitopes. The MAbs had been raised against native $S$ protein. Five domains (I-V) of S, in both S1 and S2, bound 13 of these antibodies (Fig. 5), of which sites I, III, and IV bound VN antibodies. A synthetic 13-residue peptide, conserved among MHV strains, was located within domain III (Luytjes et al., 1989). The combined data further support the view that sequences that are linearly situated far apart, e.g., domains II and V, are closely situated in the native protein, forming discontinuous epitopes.

In summary, for MHV, VN epitopes are formed largely by residues in S1, but there are some VN epitopes in S2. In some cases there may be interaction between $\mathrm{S} 1$ and S2 residues, brought into juxtaposition by the folding of the protein, to form VN epitopes, but there are also epitopes in S1 and S2 that are 
independent of each other. Some epitopes in both S1 and S2 are continuous in nature, while some VN epitopes in S1, at least, rely on conformation for antibody binding.

The $\mathrm{S}$ proteins of $\mathrm{BCV}, \mathrm{TCV}, \mathrm{HEV}, \mathrm{HCV}-\mathrm{OC} 43$, and $\mathrm{MHV}$ are antigenically related, as shown using both sera and MAbs (Hogue et al., 1984; Tijssen et al., 1990; Vautherot et al., 1990, 1992a; Michaud and Dea, 1993).

Using five MAbs in competition experiments, Deregt and Babiuk (1987) detected two nonoverlapping sites, both associated with VN antibody, in S of $\mathrm{BCV}$. Following interaction of the MAbs with fragments of $\mathrm{S}$ generated with proteases, Deregt et al. (1989a) tentatively concluded that these two VN antibody-inducing domains mapped within the S1 subunit. This was later confirmed using $\mathrm{S} 1$ that had been expressed independently of S2 using a baculovirus expression system (Yoo et al., 1990). More detailed analysis has been performed by Vautherot et al. (1992a) who used 30 anti-S MAbs. Nineteen of these defined four independent antigenic sites on $\mathrm{S} 1$, one of which $(\mathrm{S} 1 \mathrm{~B})$ was a major and the other a minor (S1-A) inducer of VN antibody. Site 1B could be subdivided. All the anti-S VN MAbs bound to S1. Some of the S1 VN MAbs failed to react with SDSdenatured polypeptides, while others did react provided that the polypeptides had not also been reduced, indicating that the epitopes were conformational. Although MAR mutants were obtained, no sequence data are available for these. However, Yoo et al. (1991b) have constructed a set of deletion mutants of $\mathrm{S} 1$, expressed them in a baculovirus system, and examined the binding of the A and B site VN MAbs of Deregt et al. (1989a). Only mutant S1 containing residues $324-720$ bound the MAbs. The hypervariable region of this group of viruses is situated in the middle of this 324-720 sequence (Fig. 4). Two immunoreactive domains were further delineated, namely, one between residues 324 and 403 situated on the $\mathrm{N}$-terminal side of the hypervariable region and one between residues 517-720, the $\mathrm{N}$-terminal portion of which is part of the hypervariable region. Mapping of the $37-\mathrm{kDa}$ trypsin fragment previously examined by Deregt et al. (1989a) further indicated that the second domain was formed by residues 517 to 621 , most of which is in the hypervariable region, and that the first domain comprised residues $351-403$. It was not possible to assign site A and B MAbs to one or other of these domains; both were required for binding of each MAb.

Six MAbs, all non-VN, defined two sites on S2 (Vautherot et al., 1992a). Analysis of prokaryotic expression products and synthetic peptides have shown that MAbs to site S2A, and no other S2 or S1 MAbs, and polyclonal sera against BCV bound to epitopes formed by residues from within the first $20 \mathrm{~N}$-terminal residues of S2 (Vautherot et al., 1992b). The recognition of these epitopes by convalescent serum showed that these epitopes induced antibodies in the host animal. MAbs to these epitopes bind not only to BCV strains but also to isolates of MHV, HEV, and HCV-OC43 (Vautherot et al., 1992a), even though there are amino acid differences in this region. A similarly situated continuous epitope has been identified at the $\mathrm{N}$-terminus of S2 of IBV, although this induced weakly neuralizing antibody (Kusters et al., 1989b; Kant et al., 1992).

The MAbs of Vautherot et al. (1992a) to the spike VN sites A and B were specific to $B C V$, whereas antibody to the other two, non-VN S1 sites (C and D) 
bound to HCV-OC43 and one S1-D MAb bound to HEV and MHV. However, some BCV site B MAbs of Michaud and Dea (1993) did bind to HCV-OC43. These MAbs were highly VN and therefore probably correspond to the A and B sites of Vautherot et al. (1992a), Deregt and Babiuk (1987), and Deregt et al. (1989a,b), which are located within and to the $\mathrm{N}$-terminal side of the hypervariable region (Yoo et al., 1991b), as described above. It would be expected that some site A and/or B MAbs would bind to HCV-OC43 since the sequence of the $\mathrm{BCV}$ antigenic domain containing residues $351-403$ is identical to that in HCVOC43 (Künkel and Herrler, 1993; Mounir and Talbot, 1993). Some variation among BCV isolates has been detected using MAbs (El-Ghorr et al., 1989; Hussain et al., 1991; Michaud and Dea, 1993). Some of the anti-S MAbs raised against the cell-adapted, attenuated Mebus strain failed to bind to virulent field strains, which is in keeping with the sequence data that show that the field isolates resemble each other more than they do the Mebus strain. In addition, some anti-Mebus spike MAbs differentiated some Quebec isolates from each other. Michaud and Dea (1993) have shown that BCV and TCV had many spike $\mathrm{VN}$ epitopes in common.

In summary, the BCV VN epitopes identified to date reside in S1, probably located near and within the hypervariable region (Fig. 4). Few of these epitopes were common to other viruses of the group, whereas there was greater conservation with respect to the non-VN epitopes in S1 and even more so for S2 epitopes. These findings are consistent with our knowledge of the $\mathrm{S}$ sequences of these viruses.

\section{IBV}

Since its isolation in 1936, many serotypes of IBV have been defined by VN tests. This antigenic variation is of great practical importance, resulting in the production of vaccines to several serotypes and/or the frequent modification of prophylaxis protocols (King and Cavanagh, 1991).

The major VN antibody sites of IBV reside in S1. This has been deduced as (1) virus from which S1 had been removed by urea did not induce VN antibody (Cavanagh, 1983c; Cavanagh and Davis, 1986); (2) urea-released S1, although in monomeric form, did induce VN, and hemagglutination-inhibiting antibody (Cavanagh and Davis, 1986); and (3) strongly neutralizing MAbs bound to S1 (Mockett et al., 1984; Koch et al., 1990; Karaca et al., 1992; Parr and Collisson, 1993) and selected MAR variants with mutations in S1 (Fig. 6) (Cavanagh et al., 1988; Koch et al., 1990; Kant et al., 1992). The dependence on conformation for the antigenicity of the S1 sites has been shown not only by the failure of anti-S1 VN MAbs to react in Western blots but also by reduced antibody binding after deglycosylation of S with glycosidases (Koch and Kant, 1990a).

One site in S2 (site G) induced weakly neutralizing antibody (Kusters et al., 1989b). Analysis with prokaryotic expression fragments and with synthetic peptides has shown that this S2 site, which is not denatured by SDS and mercaptoethanol (Koch and Kant, 1990a), is situated within the first 20 residues after the N-terminus of S2 (Fig. 6) (Lenstra et al., 1989; Kusters et al., 1989b; Posthumus et al., 1990a,b). Part of this sequence is strongly conserved among isolates with otherwise very variable $S$ sequences. A similarly situated se- 


$\begin{array}{lll}24 & 132 & 291325361 \\ 60 & 149 & 299332387 \\ 61 & & 302333394 \\ 63 & & 323334398\end{array}$

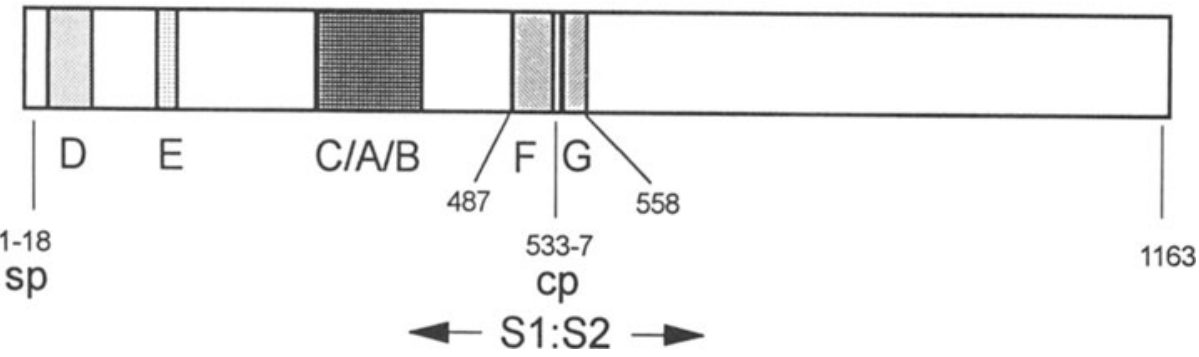

FIGURE 6. Location of some antigenic sites on the $S$ protein of IBV. Conformation-dependent sites $A$ to $E$ are associated with VN epitopes and were defined by the sequencing of MAR mutants; amino acid position 63 was identified on strain M41 and most of the others on strains of the D207 group. The numbers refer to amino acid positions relative to the D207 isolate. The order of sites A, B, and C is uncertain. MAbs to site D also inihibited hemagglutination. Sites F and G contain epitopes that are not conformation-dependent and are defined using bacterial expression products and peptides and are associated with weakly neutralizing antibodies. sp, Signal peptide; cp, basic S1-S2 connecting peptide.

quence in the S protein of BCV is also very antigenic (Vautherot et al., 1992b). Kusters et al. (1989b) have suggested that the beginning of S2 is a protruding protein segment with a high local mobility.

Competition assays with 27 anti-S MAbs resulted in the identification of six antigenic sites (A-F) in S1 of the D207 strain and two (G, H) in S2 (Fig. 6) (Koch and Kant, 1990a; Koch et al., 1990). One site, F, was defined using bacterial expression proteins and one weakly neutralizing MAb (Fig. 6) (Kusters et al., 1989b). The other five S1 sites bound VN antibody, two (D, E) and three (A, B, and C) sites being located in the first (region I) and third (region III) quarters of $S$, respectively (Figs. 6 and 7). MAR mutants selected with the VN MAbs exhibited amino acid changes at a total of 16 positions, $75 \%$ of these being in region I, the remainder in region III (Figs. 6 and 7). MAbs to site D, in addition to being VN, inhibited hemagglutination and selected MAR mutants of IBV-D207 (Kant et al., 1992) and IBV-M41 (Cavanagh et al., 1988) at positions 60-63 from the $\mathrm{N}$-terminus of S1, including signal peptide.

The entire $S$ protein gene of nine isolates of IBV has been sequenced, revealing that S1 can vary $\geqslant$ fivefold more than S2 (references in Section II.A). The amino acid differences in $\mathrm{S} 1$ are not scattered randomly but tend to be concentrated in regions I and III (Fig. 7). Among 13 strains of one serotype (Massachusetts) there were more than fivefold more variable positions in region I than in region II (Fig. 7b) (Cavanagh et al., 1988, 1992a). Since all these strains were of the same serotype, this shows that the variation in region I did not make a great impact on serotype.

In a group of seven IBV isolates, including UK/6/82 and the D207 strains used by Koch and colleagues for MAR mutant studies, in which the maximum difference between any two strains was only $5 \%$ of S1 residues, $88 \%$ of the 


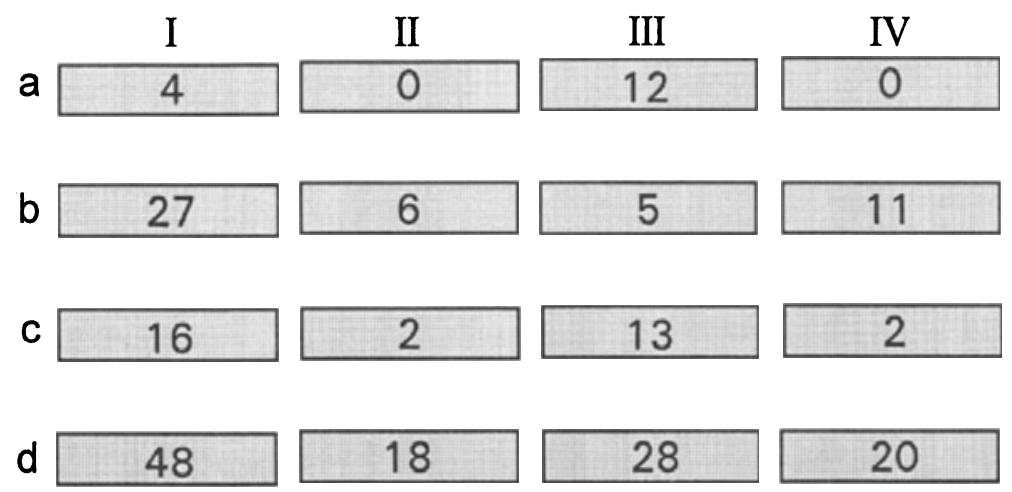

FIGURE 7. Amino acid variaton of the S1 sunbunit of the IBV spike protein. The rectangles represent the first (amino acid residues 1-130), second (131-260), third (261-391), and fourth (392 to approximately 520 ) quarters of $S 1$, signal peptide excluded. The numbers show the number of amino acid differences in each quarter for the groups of isolates specified. (a) Location of amino acid changes among 16 MAR mutants of IBV, strain D207 (Kant et al., 1992). (b) Location of amino acid differences among a group of 13 strains (excluding Beaudette) of the Massachussetts serotype (Cavanagh et al., 1988, 1992b). (c) Location of amino acid differences among a group of seven isolates, including D207 and UK/6/82, where the maximum difference between two isolates is $5 \%$ (Cavanagh et al., 1992a). (d) Number of amino acid differences between members of the UK/6/82 group and the Massachussetts M41 strain, the difference between M41 and individual members of the UK/6/82 group being approximately $20 \%$.

differences were distributed approximately equally among regions I and III (Fig. 7c) (Cavanagh et al., 1992b). Comparison of the MAR mutant and field isolate data shows that the location of changed residues in MAR mutants is very similar to that of the amino acid differences among field isolates, indicating that many of the differences in regions I and III of field isolates are associated with differences in antigenicity. Indeed, despite their overall high amino acid identity, these seven strains represented three serotypes, supporting the view that changes in these regions of S1 can be advantageous to the virus, in respect to avoidance, if only partial, of immune responses induced in chickens by prior infection. A comparison of Fig. 7a-c suggests that changes in region III may contribute more to the serotype than region I. The observation that isolates that differed by only a dozen or fewer amino acids in S1 exhibited very little crossneutralization suggests that most of the $\mathrm{VN}$ antibody was induced by a small number of immunodominant epitopes.

As the differences between serotypes rise to about $20 \%$ of $\mathrm{S1}$ residues, e.g., when the UK/6/82 group is compared with the Massachusetts M41 strain, the number of amino acid differences in regions II and IV does increase, but there is also a marked increase in the number of changes in regions I and III (Fig. 7d) (Cavanagh et al., 1992a, Cavanagh and Davis, 1992). To what extent changes in regions II and IV contribute to antigenic variation is not known.

Recently, the sequence of S1 of several of the "classical" North American reference isolates has been determined, including the Arkansas 99 (Ark99) isolate (Wang et al., 1993; Jia et al., 1993a), SE17 and Pp14 (Wang et al., 1993), 
Gray (Kwon and Jackwood, 1993; Wang and Collisson, 1993), and JMK (Kwon and Jackwood, 1993), Holte (Wang and Collisson, 1993), CU-T2 (Jia et al., 1993a), Iowa-609 (Wang et al., 1994) and parts of S1 for the Connecticut-46 and Florida isolates and two strains recently isolated in Delaware (J. Gelb, C. Keeler, and W.A. Nix, personal communication). This has revealed that some of these strains differ substantially from each other (about $20 \%$ of S1 residues), while other isolates have high identity (>95\%). The Gray and JMK strains share $98 \%$ identity, consistent with them being placed in the same serotype (Hopkins, 1974). However, Hopkins, unlike Johnson and Marquardt (1975), placed the Holte strain in the same serotype as JMK, whereas they differ by about $27 \%$ in the first 200 or so amino acids of S1. Similarly, Johnson and Marquardt considered that the Ark99 and Connecticut-46 were different serotypes, consistent with the finding that they differ by $29 \%$ in the first 200 residues, whereas Hopkins placed them in the same serotype. These results further indicate that serology is not a firm foundation on which to build a system for establishing relationships between IBV isolates.

The first 350 or so residues of S1 of many Australian strains, isolated over a 30-year period, have recently been determined (S. Sapats, P. J. Wright, and Y. Ignjatovic, personal communication). Comparisons show that many isolates obtained in the 1960s and 1970s had about $80 \%$ identity with each other and with several European and North American strains in this part of S1. Most interestingly, however, two strains isolated in different parts of Australia in the same year (N1/88 and Q3/88) had only $67 \%$ identity with each other over the whole of $\mathrm{Sl}$ and had percentage differences in the first 350 residues of about $55 \%$ (suggesting a possible difference of about $67 \%$ for the whole of S1) when compared with earlier Australian isolates and with non-Australian strains. Only vaccines based on Australian isolates have ever been permitted in Australia, and importation of live poultry was banned 50 years ago. Thus Australian strains of IBV may have been evolving independently, at least for the lifetime of the intensive poultry industry.

Another contributor to IBV variation is recombination during mixed infection, and there is sequence evidence that indicates that recombination has occurred within the S gene (Kusters et al., 1989a, 1990; Cavanagh et al., 1992a; Wang et al., 1993; Jia et al., 1993b). One consequence is that characterizing an IBV isolate by partial sequencing of S1 may not always result in the establishment of a more accurate relationship between two strains than has been achieved by serological analysis. Where it is important to establish the degree of relatedness of strains it would be advisable to sequence more than one part of $S$ and also part of another gene.

\section{INDUCTION OF PROTECTIVE IMMUNITY}

There is strong evidence that the $\mathrm{S}$ protein is a major inducer of protective immune responses, although the other structural proteins undoubtedly also play a role (see Chapters 6 and 8 , this volume). C57 BL/10 strain mice were protected from a lethal infection of MHV-3 by immunization with sucrose 
gradient-purified S (Hasony and Macnaughton, 1981), as were BALB/C mice immunized with affinity-purified S and challenged with MHV-A59 (Daniel and Talbot, 1990), although there were some clinical signs. Some anti-S MAbs also gave a measure of protection against MHV (Nakanaga et al., 1986; Koolen et al., 1990). When the MHV-A59 S protein was expressed in mice using an adenovirus vector, $50-90 \%$ of the mice, dependent on the challenge dose, were protected against the lethal effects of intracerebral A59 infection (Wesseling et al., 1993). A recombinant adenovirus expressing the $\mathrm{N}$ protein also induced protective immunity, the protection being greater when $\mathrm{N}$ and $\mathrm{S}$ were jointly expressed compared with either protein alone. A peptide corresponding to a nine amino acid sequence located 131 residues from the amino-terminus of S2 (Fig. 5) (Luytjes et al., 1989) induced protection in mice (Koolen et al., 1990). This sequence has also been expressed as a chimeric protein including the VP2 capsid protein of a human parvovirus, expressed by a recombinant baculovirus (Brown et al., 1994). Sixty percent of mice vaccinated with a chimeric protein and subsequently challenged with MHV A59 survived the challenge.

IBV from which the S1 subunit had been removed by urea was unable to induce immunity to respiratory infection in chickens (Cavanagh et al., 1986c), indicating that the S protein, and possibly the S1 subunit in particular, was required for immunity. Chickens vaccinated with live vaccine of one IBV serotype are frequently poorly protected against challenge by other serotypes (Johnson and Marquardt, 1975). Since the S protein varies to a greater extent than the other virion proteins and given the experimental evidence for a major role in protection played by the $S$ protein, it is likely that poor cross-protection is due in large measure to differences in the epitopes of the $S$ protein.

Epitopes on the $S$ protein of TGEV are more immunogenic in pigs than epitopes on the $\mathrm{N}$ and $\mathrm{M}$ proteins and are considered to be of major importance in the induction of lactogenic immunity (Diego et al., 1992). Vaccination of cats against FIPV can be disadvantageous since antiviral antibodies lead to enhancement of infectivity of FIPV for monocytes and macrophages, leading to death of the animal (early death syndrome). That the $S$ protein is involved has been shown by vaccinating cats with a vaccinia virus recombinant expressing the FIPV S protein; the cats succumbed earlier than controls after challenge with FIPV (Vennema et al., 1990a,d).

\section{BIOLOGICAL FUNCTIONS}

\section{A. Primary Attachment to Cells}

This section concerns the virus components that mediate attachment to cells; cell receptors for coronaviruses are discussed in Chapter 4. It is generally assumed that the attachment of coronaviruses to cells is mediated by the $\mathrm{S}$ protein (Collins et al., 1992), especially in the absence of the HE protein. Many, although not all, VN MAbs are directed against S (see Section III). Some coronaviruses that do not have a HE protein can cause hemagglutination (HA). IBV can cause HA, although this is inefficient. In the past, manifestation of the HA 
capacity of IBV has involved concentration of the virus and treatment with a crude preparation of Clostridium welchii phospholipase C type I (Bingham et al., 1975; Cavanagh and Davis, 1986). A recent study has shown that treatment of IBV with purified neuraminidase (from Vibrio cholerae and from Newcastle disease virus) efficiently converts IBV into good HA material, indicating that it was the presence of small amounts of neuraminidase that had been effective in the crude bacterial extracts (Schultze et al., 1992). Neuraminidase treatment of erythrocytes abolished HA with neuraminidase-treated IBV. This indicates that sialic acid (a2,6 linkage) on the erythrocytes was acting as a receptor. It is unclear why neuraminidase treatment of the virus enhanced HA. One reason may be that cellular material was attached to the S protein, via a sialic acid link, and that the neuraminidase "cleaned" this off. That it is the S protein that is responsible for attachment of IBV has been shown in a number of ways. Some MAbs reactive with S (Mockett et al., 1984) and polyclonal antibody raised against purified S (Cavanagh et al., 1984) inhibited HA. Moreover, the HAinhibiting antibody was associated with the S1 subunit (Mockett et al., 1984; Cavanagh et al., 1986c), virus lacking S1 could not cause HA and was noninfectious (Cavanagh et al., 1986c) and the HA-inhibiting MAbs also had VN activity. Porcine TGEV that, like IBV, does not have an HE protein can also cause HA (Noda et al., 1987, 1988).

The HE protein, present in a subset of the coronaviruses, can also attach to erythrocytes (see Chapter 8, this volume). Schultze et al. (1991) have purified the $S$ and $\mathrm{HE}$ proteins of $\mathrm{BCV}$. Both proteins recognized the same type of sialic acid receptor, but the $S$ protein caused HA more efficiently than did HE. They proposed that $\mathrm{S}$ was responsible for the primary attachment of the virus to cells.

\section{B. Membrane Fusion}

Great care must be taken when generalizations are made about coronaviruses, not least where membrane fusion is concerned. It can be stated that S-induced cell-cell fusion (syncytium formation) does not have an absolute requirement for cleavage of $S$. Indeed, the $S$ protein of members of the TGEV group is not cleaved but can induce syncytia. For those coronaviruses that do produce a cleaved S, prevention of cleavage does not necessarily result in the loss of fusion activity, although it results in less efficient fusion induction. No single sequence solely responsible for fusion has been identified. Indeed, the evidence to date is that several regions, in terms of the linear $\mathrm{S}$ molecule, influence fusogenic activity. With regard to $\mathrm{pH}$, the spike protein of many strains of all coronavirus species so far examined will induce cell-cell fusion optimally at neutral $\mathrm{pH}$ and slightly above. For these viruses, fusion of an incoming virion with a cell membrane is affected little or not at all by lysosomotropic agents, since there is no detrimental effect on the successful infection of cells. Since lysosomotropic agents raise the $\mathrm{pH}$ in endosomes away from acidity, this indicates that virion-cell fusion either occurs at the cell surface or within endosomes prior to their acidification. However, there are some very interesting exceptions to this general observation. 


\section{Evidence for the Role of $S$ in Fusion}

Expression of the S gene of FIPV and MHV-JHM using virus vectors has provided unequivocal evidence that $S$ alone among the virus proteins is required for syncytium formation (de Groot et al., 1989; Pfleiderer et al., 1990; Grosse and Siddell, 1994). The identification of a fusion domain has not proven possible, given that sequences in both $\mathrm{S} 1$ and $\mathrm{S} 2$ glycopolypeptides are involved and that the three-dimensional structure of $S$ has not been deduced. Bacterial expression products, containing nonconformational epitopes, corresponding to both S1 and S2 sequences have induced MAbs with fusion-inhibiting activity (Routledge et al., 1991). A nine-residue peptide, corresponding to the sequence beginning 131 residues from the N-terminus of S2 (strain A59), binds a fusioninhibiting site A MAb (Luytjes et al., 1989) (position 900-908 in Fig. 5a). Recombination experiments have also supported the view that S2 of MHV is involved in fusion (Keck et al., 1988) and S2 of BCV expressed in insect cells caused cell fusion (Yoo et al., 1991a). Amino acids in both of the hydrophobic regions of $S 2$ that exhibit heptad repeats and are believed to form the coiled-coil structure of the oligomeric $S$ protein have been associated with fusion activity (Fig. 5e). Gallagher et al. (1991) identified three residues, at positions 1067, 1094, and 1114 in the MHV4 S protein, which together were associated with the loss of fusion at neutral $\mathrm{pH}$ and a requirement of acidic $\mathrm{pH}$, although it is not clear exactly how these changes cause such a marked effect on fusion (Fig. 5e). A peptide corresponding to residues 1264-1276 of MHV4 induced MAb 10G, which had both VN and antifusion activity (Fig. 5) (Routledge et al., 1991). In the same study a peptide of residues 33-40, i.e., near the N-terminus of S1, also had both of these activities. The anti-S2 MAb 10G might destabilize the oligomeric structure of $S$ and thereby interfere with the interaction of the fusogenic region with a cell membrane. A similar explanation may apply to MAb 19.2, which inhibits fusion and binds to a linear sequence within antigenic domain III (Lutyjes et al., 1989; Daniel et al., 1993), although this is not located directly within the hydrophobic areas (Fig. 5). It must be remembered, however, that $S$ protein-induced cell-cell fusion is at least a two-step process, the fusion event being necessarily preceded by the attachment of the $S$ protein, anchored in the plasma membrane of a cell, to the surface of an adjacent cell. Cells that were expressing the S protein of FIPV or MHV, following infection with a vector carrying the relevant $S$ gene, fused with cocultivated cells when those cells were of a type that were susceptible to FIPV or MHV infection, respectively, but not to cells that were refractory to infection with these viruses (de Groot et al., 1989; Vennema et al., 1990b,c). This not only indicates that S must first attach to a receptor prior to fusion, but also that there is some specificity in that attachment. Taguchi et al. (1992) have shown, however, that vaccinia virus expression of MHV S resulted in fusion not only in murine cells but also in rabbit RK13 cells, which are refractory to infection but would appear to have a receptor for $\mathrm{MHV}$, strain cl-2. It may be that MAbs that inhibit fusion might do so either by inhibiting attachment of $S$ to cell membranes (where $S$ can be either on virions or on the surface on an infected cell, adjacent to a noninfected one) or the fusion event. Some site A and B MAbs of MHV neutralize virus in addition 
to inhibiting fusion. The VN and antifusion MAb $11 F$ that binds near the beginning of $\mathrm{S} 1$ (Fig. 5c) could interfere with the attachment process, thereby indirectly affecting fusion. Alternatively, residues 33-40 may be in close proximity to residues 1264-1319 in the native protein, this association being necessary for fusogenic activity; hence, this activity would be inhibited to antibodies against either linear location. A third possibility is suggested by the observation that MAR mutants selected by MAb 11F had mutations not in residues 33-40, which are known to have induced MAb 11F (Routledge et al., 1991), but in S2 residues 1109, 1110, and 1116 (Grosse and Siddell, 1994). Sturman et al. (1990) have shown with MHV that mildly alkaline conditions result in the irreversible dissocation of S1 and S2. Furthermore, they have suggested that this event is necessary for fusion activity. It has been proposed (S. G. Siddell, personal communication) that MAb $11 \mathrm{~F}$ might interfere with this dissociation process, given that the residues $33-40$ would seem to be closely associated with residues $1109-1116$ in the mature $S$ protein. It should be remembered that the $S$ proteins of some coronaviruses, e.g., those of the TGEV group, are not cleaved into S1 and S2 glycopolypeptides (Sections I.B.2 and IV.B.3). Therefore, if rearrangement of the $\mathrm{N}$-terminal and $\mathrm{C}$-terminal halves of $\mathrm{S}$ is a part of the fusionactivation process, this does not necessarily result in the total separation of $\mathrm{S} 1$ and S2. Knowledge of the three-dimensional structure of $S$ would greatly facilitate interpretation of these data.

\section{Role of $\mathrm{pH}$ in Fusion}

There are two stages at which the fusogenic role of $S$ may come into play, the first of which can be considered essential for natural infection. First, the virion membrane must fuse with a cell membrane to release the genome into the cytoplasm. Second, newly produced S protein may, on being transported to the plasma membrane, cause an infected cell to fuse to an adjacent, noninfected cell, thereby allowing spread of the infection without the absolute necessity for release of virions into the extracellular environment. Many investigations of the $\mathrm{pH}$ requirements for coronavirus fusion have focused on cell-cell fusion, to form syncytia, either by the addition of large amounts of virus to cells to give rapid syncytium formation [fusion from without (FFWO), a gross example of virion-cell fusion] or simply by observing syncytium formation after virus replication [fusion from within (FFWI)]. The virion-cell membrane fusion that results in genome uncoating has been studied by addition of lysosomotropic agents (ammonium chloride, chloroquine). These raise the $\mathrm{pH}$ in endosomes, the vesicles in which viruses become surrounded if they do not fuse at the cell surface, from $<6.0$ to almost 7.0. The rationale is that if infection is inhibited or greatly decreased by a lysosomotropic agent, this is indicative that an acidic environment is necessary for activation of the fusion protein.

Observation of fusion induction by the S protein of MHV, FIPV, BCV, and IBV have shown that for many strains fusion (virion-cell and cell-cell) occurs optimally at about $\mathrm{pH} 7.0$ or slightly greater. This has been shown by experiments on FFWO with MHV-A59 (Sturman et al., 1985; Frana et al., 1985; Kooi et al., 1991) and on FFWI following MHV4 replication (Gallagher et al., 1991). 
MHV-induced FFWI was inhibited when the culture medium had a $\mathrm{pH}<7.0$ (Sawicki and Sawicki, 1986). Similar observations have been made with BCV (Payne and Storz, 1988). Neutral pH was sufficient for FFWI following expression of FIPV and MHV S protein from vaccinia virus vectors (de Groot et al., 1989; Vennema et al., 1990b,c; Pfleiderer et al., 1990; Taguchi et al., 1992; Stauber et al., 1993). Lysosomotropic agents had little effect on the infection on cells by BCV and IBV strain UK/123/82 (Payne and Storz, 1988; Li and Cavanagh, $1990,1992)$. Electron microscope observations showed fusion of BCV virions at the cell surface but not at internal membranes.

Kryzstyniak and Dupuy (1984) reported that infection by MHV3 was greatly diminished by lysosomotropic agents. Mizzen et al. (1985) found that ammonium chloride did not decrease the number of cells infected but did extend the eclipse phase. That is, in the presence of the agent, virus was transferred from the cell surface (as shown by resistance of proteinase- $\mathrm{K}$ treatment of the cells) and remained as infectious virus within the cells for an appreciably longer time than in the absence of ammonium chloride. However, even in the presence of ammonium chloride the cells ultimately became infected, and virus yields were the same as the controls. Kooi et al. (1991) have confirmed that ammonium chloride delays the appearance of new virus by about $4 \mathrm{hr}$ and that the final titers were the same as in the controls. In parallel experiments the titer of vesicular stomatitis virus, a virus known to require an acidic $\mathrm{pH}$ for fusion, was greatly reduced in the presence of the lysosomotropic agent. These authors also showed that MHV-A59 was endocytosed by Vero and rat astrocytoma (C6) cells, but this did not lead to productive infection. The latter did occur after cells to which virus had attached were treated with polyethylene glycol to cause fusion at the cell surface. This agreed with the earlier work of Van Dinter and Flintoff (1987). The interpretation of these results is that although MHV-A59 can be endocytosed, this may result in transfer of virus to lysosomes, where it is destroyed. Rather, it is considered that the fusion of MHV-A59 virions with cells is not dependent on endocytosis and certainly not on an acidic environment, and occurs at the cell surface or possibly in endocytic vesicles and/or endosomes prior to acidification.

There are, however, exceptions to these observations. The productive infection of Vero and CK cells by IBV-Beaudette (in contrast to the UK/123/82 strain) was reduced by $80-95 \%$ when ammonium chloride was present early in infection, with a corresponding $0.9 \log _{10}$ decrease in subsequent virus production by $10 \mathrm{hr}$ postinfection, near the end of the first replication cycle (Li and Cavanagh, 1990, 1992). Syncytium formation by FFWI occurred optimally at $\mathrm{pH}$ 6.7. These results suggest that IBV-Beaudette virions fuse shortly after transfer to endosomes in a slightly acidic environment. Electron microscope investigations of the entry of IBV-Beaudette into chorioallantoic cells and CK cells did not reveal any fusion of the virus at the cell surface but did observe entry by endocytosis (Chasey and Alexander, 1976; Patterson and Bingham, 1976). In contrast, Payne et al. (1990) observed that $\mathrm{BCV}$ fused with plasma membrane but not with endosomal membranes, consistent with the observation that ammonium chloride had little inhibitory effect on BCV infection.

A more dramatic example has been described by Gallagher et al. (1991). 
They showed that MHV4, in susceptible murine DBT and Sac- cells, caused syncytium formation by FFWI at $\mathrm{pH} 5.5-8.5$, the optimum being at $\mathrm{pH} 7.0$ and above. Lysosomotropic agents did not reduce replication, as assessed by the rate of viral RNA synthesis, although there was a delay in the time taken for peak production in the presence of chloroquine. However, variants of MHV4 obtained from a persistently infected neural cell line caused little or no fusion in DBT or Sac - cells at $\mathrm{pH} 7.0$ and above. Instead, the optimum $\mathrm{pH}$ for fusion was 5.5-6.0. Correspondingly, productive infection by these mutants was inhibited substantially by lysosomotropic agents. The mutations corresponding to this changed phenotype were located in the larger of the heptad repeat areas of S2 (Fig. 5e). Passage of the acid $\mathrm{pH}$-dependent variants in Sac- cells resulted in selection of neutral $\mathrm{pH}$-fusing revertants. Ammonium chloride and chloroquine did not prevent replication of the revertants, although, as with MHV-A59 (Mizzen et al., 1985; Kooi et al., 1991), they delayed virus replication by a few hours.

The work of Gallagher et al. (1991) has shown that cell type was of paramount importance in the selection of MHV4 variants with greatly differing $\mathrm{pH}$ requirements for fusion. One suggestion by Gallagher et al. (1991) as to why low $\mathrm{pH}$-dependent virus was selected in OBL21A cells is that it may be unable to fuse at the cell surface but can fuse after transfer to endosomes, because of some difference in the membranes. It has been shown that the composition of the membrane, for example, with respect to cholesterol, can effect membrane fusion (Daya et al., 1988; Roos et al., 1990; Kooi et al., 1991). However, it does not necessarily follow that the spike protein gene should mutate to give a low $\mathrm{pH}$-dependant protein. An alternative hypothesis (Gallagher et al., 1991) is that sustained replication in OBL21A neural cells might require that the incoming nucleocapsid becomes available deep within the cell and not just beneath the surface. This would be more likely to happen if the $\mathrm{S}$ protein required a low $\mathrm{pH}$ for fusion activation, achieved when the endosomes had traveled away from the cell surface. They further speculate that $\mathrm{Sac}-$ cells selected neutral $\mathrm{pH}$ requiring revertants because syncytium formation is advantageous to the spread of the virus.

In any event, the stage of nucleocapsid release from coronavirus virions is one that can be affected by cell type and may be a factor in determining host cell range and pathogenesis. Kooi et al. (1988) have further data that support the view that the degree to which cells are permissive to MHV can depend on the efficiency of the fusion process leading to the release of the nucleocapsid. Beushausen et al. (1987) have presented evidence that suggests that differentiated rat oligodendrocytes are resistant to MHV infection because normal processing of the phosphorylated nucleocapsid protein is inhibited in some manner.

\section{Requirement of Cleavage for Fusion}

Whether or not cleavage of the coronavirus $S$ protein is required for its fusogenic activity has been studied in several ways, including the simple expedient of determining whether each coronavirus had cleaved or uncleaved $S$ in its 
virions. Experiments involved FFWO and FFWI, with and without trypsin treatment, and expression of the $S$ protein using virus vectors, with and without mutant $S$ genes. Some coronaviruses produce virions with up to $100 \%$ cleaved $S$, while others have never been observed to have cleaved S (see Section I.C). Virions of both types are infectious, showing that cleavage is not essential for virus-cell fusion. However, several studies during the 1980s indicated that only cleaved $\mathrm{S}$ would induce fusion of one cell with another to produce syncytia.

MHV-A59 from Sac- cells, which had $100 \%$ of $S$ in the cleaved form, was able to cause FFWO when added to L2 cells (Frana et al., 1985). In contrast, MHV-A59 virus from $17 \mathrm{Cl} 1$ cells, which had about $50 \%$ cleaved S (Frana et al., 1985), was unable to cause FFWO unless it had previously been treated with trypsin to complete the cleavage process (Sturman et al., 1985). Similarly, BCVL9 only caused FFWI and plaque formation when trypsin was used to increase the proportion of cleaved S from 30-60\% to almost 100\% (Storz et al., 1981; Payne and Storz, 1988; Cyr-Coats et al., 1988). A variant of MHV-A59, which had no cleaved S, produced only small plaques and also did not cause cell fusion (Sawicki, 1987). IBV-Beaudette-induced FFWI of Vero cells was increased if trypsin was present, the effect being most marked with virus that had not been previously adapted to growth in Vero cells. Plaque development was also enhanced (D. Li and D. Cavanagh, unpublished observation). However, virions of both no, low, and high Vero cell-passaged virus had the same proportion (approximately 1:2) of uncleaved to cleaved S.

Initially these experiments were interpreted as showing that for viruses that had a spike that was capable of being cleaved into S1 and S2, cleavage was necessary for fusogenic activity leading to syncytium formation. An alternative interpretation is that, for these coronaviruses, both cleaved and uncleaved $S$ has fusogenic activity but that cleaved $S$ is more fusogenic. In those cases where addition of trypsin enhanced cell-cell fusion, it would then be concluded that prior to the addition of trypsin there was not enough $S$ at the cell surface capable of efficiently forming sufficient microfusion events that would ultimately coalesce to form syncytia. Extraneous trypsin cleaved the uncleaved S molecules, thereby increasing the number and concentration of efficiently fusogenic $S$ molecules to above a threshold value, gross fusion then occurring.

This alternative view arises in part from experiments in which S proteins have been expressed using virus vectors. A cleaved form of the spike of FIPV has never been observed. When the FIPV S protein was expressed using a vaccinia virus recombinant, syncytium formation resulted (de Groot et al., 1989). To determine if uncleaved S of MHV-JHM would induce syncytia, Stauber et al. (1993) and Taguchi (1993) mutated the highly basic S1-S2 connecting peptide (Arg-Arg-Ala-Arg-Arg) to Ser-Val-Ser-Gly-Gly and Arg-Thr-Ala-Leu-Glu, respectively. When expressed, the mutant spikes were not cleaved, but they did induce cell-cell fusion. Taguchi (1993) observed a 2- to 4-hr delay in fusion in the cells expressing the mutant $S$, suggesting that although uncleaved $S$ was fusogenic, it was perhaps less efficient than cleaved $S$.

Additional support for this conclusion was provided by Gombold et al. (1993), who examined mutant MHV-A59 isolated from productively but persistently infected primary mouse glial cell cultures. The mutants grew normally 
in L2 cells, but, whereas wild-type virus had caused almost $100 \%$ fusion of the monolayer by $10 \mathrm{hr}$ after infection, the mutants had caused less than $10 \%$ fusion. Reduction of the $\mathrm{pH}$ had no enhancing effect on fusion, but trypsin did do so for several mutants, which in the absence of the enzyme produced only uncleaved S. Sequencing revealed that the mutants had the connecting peptide Arg-Arg-Ala-Asp-Arg instead of the wild-type Arg-Arg-Ala-His-Arg, i.e., a negatively charged aspartic acid residue in place of a weakly basic histidine. Analysis of revertants, which produced cleaved S and fused cells efficiently, showed that all the revertants had lost the aspartic acid residue in the connecting peptide, it having been replaced by the wild-type histidine in one case but by the small, uncharged residues alanine or glycine in others. These results showed that the presence of a negatively charged residue one position away from the $\mathrm{C}$-terminal end of the S1-S2 connecting peptide prevented cleavage; that a basic residue at this position was not essential for cleavage; and that while cleaved $S$ was not required for virus-cell fusion and was not essential for cell-cell fusion, uncleaved $S$ was less efficient at inducing cell-cell fusion. The observation that virions of $\mathrm{MHV}$ and $\mathrm{BCV}$ with $50 \%$ or less cleaved S are infectious also shows that cleavage of all the $S$ molecules is not necessary for the fusion between virion and cell membranes that results in genome uncoating.

The seemingly greater capacity of the $S$ protein to fuse virions with cell membranes may be because the concentration of $S$ molecules in the virion envelope may be greater than at the surface of an infected cell. If this is the case, then virions would be expected to cause more microfusion events, in close proximity to each other, resulting in fusion. Syncytium formation is a rather gross manifestation of S-induced membrane fusion, a process that is probably preceded by small, localized fusion events between adjacent cells. If this is the case, then it may be the progression from the localized to the extensive fusion that requires a particularly high density of cleaved S.

In conclusion, the process by which the coronavirus $S$ protein induces membrane fusion would seem to be a complex, stepwise one. Interaction of the $S$ protein with a cell surface may require primary and secondary receptors. This attachment process may induce conformational changes that ultimately result in gross changes in the juxtaposition of S1 and S2 sequences, followed by membrane fusion. Protonation is not required in most cases.

\section{ROLE OF S IN PATHOGENICITY}

It is likely that the coronavirus spike glycoprotein is a major determinant of cell tropism and hence of pathogenicity. However, in very few, if any, cases can it be definitively stated that a change in the $S$ protein was responsible for a different biological behavior. In some mutants, genes encoding other proteins are known to have changes, while in all mutants there may well be mutations in other genes that have not been detected. Infectious DNA copies of coronavirus genomes will be required to obtain unequivocal answers about the role of the $S$ protein in the varied pathogenicity of coronaviruses. However, it is 
worth highlighting those cases in which changes in virulence or tropism have been paralleled by changes, sometimes very marked ones, in S.

Several members of the TGEV group exhibit $>90 \%$ amino acid identity in the S protein except for the first 200-300 residues, which are either missing or have identities as low as $30 \%$ (Fig. 3; Section III B 1). The most stiking example, perhaps, is that of TGEV compared with its mutant PRCV, with their tropisms for the alimentary and respiratory tracts, respectively. From the $S$ gene to the poly-A tract there is $98 \%$ identity overall, except that PRCV lacks the first 224 amino acids of the TGEV spike. It is very tempting to believe that this deletion is responsible for the different tropisms of these viruses, one of which (PRCV) causes mild, sometimes inapparent, disease, while the other (TGEV) is frequently lethal for piglets. However, it is known that there are a few differences elsewhere in the genome, including some in gene 3 that have effectively resulted in the loss of the 3a open reading frame.

Variation within S of FIPV may be responsible for differences in pathogenicity. Avirulent strains of FIPV were internalized less rapidly than virulent strains, from which they could be distinguished by anti-S MAbs (Fiscus and Teramoto, 1987b).

Likewise, the hypothesis that many of the different tropisms exhibited by MHV strains and other similar coronaviruses are the result of differences in $\mathrm{S}$ is very attractive. In particular, the hypervariable region of $\mathrm{S} 1$ (Fig. 5) is a prime candidate for a determinant of pathogenicity. Strains of MHV cause a broad spectrum of CNS diseases in rodents as well as replicating in various non-CNS tissues (Matsubara et al., 1991). Many of the neuroattenuated variants have arisen during passage in tissue culture. The MHV4 strain may be considered as a prototype MHV strain. Passage in tissue culture has resulted in the loss, for example, of 141 amino acids from the hypervariable region of $S 1$ to generate the JHM strain (Fig. 5), which prior to sequencing had been considered to be identical to MHV4 (Baybutt et al., 1984; Parker et al., 1989; Gallagher et al., 1990).

Interestingly, analysis of MHV-JHM mRNA obtained from the brains of Lewis rats at 5 to 7 days after intracerebral inoculation showed that the $S$ mRNA was larger than that of the input virus (Taguchi et al., 1985). Virus isolated at the same time produced the larger $S$ mRNA during replication in vitro, and produced a correspondingly enlarged S protein. It is likely that the inoculum was a mixed population, a small proportion of which had a "full-size" $S$ protein very similar to the MHV4 virus from which the JHM strain had been derived. Back-passage of the virus in rats then selected the virus with the fulllength S.

Morris et al. $(1989,1990)$ isolated variants from the CNS of Wistar Furth rats after infection with MHV-JHM, and two of these variants have been sequenced by La Monica et al. (1991). One variant lacked the codons encoding the C-terminal 246 amino acids of the HE protein and had a 147 amino acid deletion in S1 (286 residues when compared with MHV4) (Fig. 5b). This variant caused demyelination in both 2 - and 10-day-old rats, whereas the wild-type virus only produced this in the 10-day-olds, causing an acute encephalitis virus in 2-dayold rats. Another variant, which induced acute encephalitis in rats of both ages, did not have the deletion in S but did have a deletion in the HE gene. 
A neural cell line persistently infected with MHV4 selected variants that had a dependence on low $\mathrm{pH}$ for membrane fusion, in contrast to wild-type virus (Gallagher et al., 1991). Three mutations responsible for this were identified in S2 (Fig. 5e). The authors suggested that this would favor virus fusion in endosomes rather than at the cell surface, releasing the nucleocapsid deeper within the cell, this being required for some unknown reason. Revertants were selected when the mutants were back-passaged in Sac- cells; the revertants, unlike the mutants, caused extensive syncytia formation. This enables virus to spread without the necessity of being released from cells; this may be an advantage in some instances. Different, fusion-related mutations were identified by Gombold et al. (1993) after MHV-A59 had established productive persistent infection in mouse glial cells. The mutants had an altered S1-S2 connecting peptide and the spike was not cleaved and did not cause cell-cell fusion. Thus the spread of such mutants was limited to that attained by virions released from cells. A related example of a change in biological properties of MHV coincident with a change in $S$ has been described by Fazakerley et al. (1992). A MAR mutant that had a 149 amino acid deletion in S1 had a neuroattenuated phenotype, considered to be a result of its reduced rate of spread in the CNS. Some other, similar deletion mutants have been selected from MHV4 stocks by VN MAbs. In four cell lines several such mutants had enhanced growth compared with the wild-type virus, attributed to delayed or diminished cytopathic effect, allowing cultures to support virus production for longer periods (Gallagher et al., 1990).

Two MAb-selected variants of MHV-3 had a changed tissue tropism, the mutants accumulating more in the lung and kidneys rather than in the liver, the primary target organ of the wild-type virus (Martin et al., 1990).

The $S$ protein can affect the outcome of infection in other ways. MHV-JHM spike on the surface of infected cells can bind IgG via the Fc domain/Oleszak and Leibowitz, 1990). MHV-infected cells were lysed in the presence of spleen and lymph node cells from nonimmunized mice, leading to the proposal that $S$ on the cell surface had, at neutral $\mathrm{pH}$, caused fusion of the infected cell and those of the B cell lineage (Wysocka et al., 1989).

ACKNOWLEDGMENTS. I would like to thank the following for providing me with data prior to publication: Jack Gelb, Jagoda Ignjatovic, Mark Jackwood, Hubert Laude, Syed Naqi, and Willy Spaan.

\section{REFERENCES}

Abraham, S., Kienzle, T. E., Lapps, W., and Brian, D. A., 1990, Deduced sequence of the bovine coronavirus spike protein and identification of the internal proteolytic cleavage site, Virology 176:296.

Arpin, N., and Talbot, P. J., 1990, Molecular characterization of the 229E strain of human coronavirus, in: Coronaviruses and Their Diseases (D. Cavanagh and T. D. K. Brown, eds.), pp. 73-80, Plenum Press, New York.

Banner, L. R., Keck, J. G., and Lai, M. M. C., 1990, A clustering of RNA recombination sites adjacent to a hypervariable region of the peplomer gene of murine coronavirus, Virology 175:548.

Baybutt, H. N., Wege, H., Carter, M. J., and ter Meulen, V., 1984, Adaptation of coronavirus JHM to persistent infection of murine Sac/-| cells, J. Gen. Virol. 65:915. 
Beushausen, S., Narindrasorasak, S., Sanwal, B. D., and Dales, S., 1987, In vivo and in vitro models of demyelinating disease: Activation of the adenylate cyclase system influences JHM virus expression in explanted rat oligodendrocytes, J. Virol. 61:3795.

Bingham, R. W., Madge, M. H., and Tyrrell, D. A., 1975, Haemagglutination by avian infectious bronchitis virus-a coronavirus, J. Gen. Virol. 28:381.

Binns, M. M., Boursnell, M. E. G., Cavanagh, D., Pappin, D. J. C., and Brown, T. D. K., 1985, Cloning and sequencing of the gene encoding the spike protein of the coronavirus IBV, J. Gen. Virol. 66:719.

Binns, M. M., Boursnell, M. E. G., Tomley, F. M., and Brown, T. D. K., 1986, Comparison of the spike precursor sequences of coronavirus IBV strains M41 and 6/82 with that of IBV Beaudette, J. Gen. Virol. 67:2825.

Boireau, P., Cruciere, C., and Laporte, J., 1990, Nucleotide sequence of the glycoprotein S (E2) gene of the bovine enteric coronavirus; comparison with mouse hepatitis virus, J. Gen. Virol. 71:487.

Bosch, F. X., Garten, W., Klenk, H-D., and Rott, R., 1981, Proteolytic cleavage of influenza virus hemagglutinins: Primary structure of the connecting peptide between $\mathrm{HA}$, and $\mathrm{HA}_{2}$ determines proteolytic cleavability and pathogenicity of avian influenza viruses, Virology 113:725.

Britton, P., 1991, Coronavirus motif, Nature 353:394.

Britton, P., and Page, K. W., 1990, Sequence of the S gene from a virulent British field isolate of transmissible gastroenteritis virus, Virus Res. 18:71.

Britton, P., Mawditt, K. L., and Page, K. W., 1991, The cloning and sequencing of the virion protein genes from a British isolate of porcine respiratory coronavirus: Comparison with transmissible gastroenteritis virus genes, Virus Res. 21:181.

Brown, C. S., Welling-Wester, S., Feijlbrief, M., van Lent, J. W. M., and Spaan, W. J. M., 1994, Chimeric parvovirus B19 capsids for the presentation of foreign epitopes, Virology 198:477.

Callebaut, P. E., and Pensaert, M. B., 1980, Characterisation and isolation of structural polypeptides in haemagglutinating encephalomyelitis virus, J. Gen. Virol. 48:193.

Callebaut, P., Correa, I., Pensaert, M., Jiménez, G., and Enjuanes, L., 1988, Antigenic differentiation between transmissible gastroenteritis virus of swine and a related porcine respiratory coronavirus, J. Gen. Virol. 69:1725.

Cavanagh, D., 1981, Structural polypeptides of coronavirus IBV, J. Gen. Virol. 53:93.

Cavanagh, D., 1983a, Coronavirus IBV glycopolypeptides: Size of their polypeptide moieties and nature of their oligosaccharides, J. Gen. Virol. 64:1187.

Cavanagh, D., 1983b, Coronavirus IBV: Further evidence that the surface projections are associated with two glycopolypeptides, I. Gen. Virol. 64:1787.

Cavanagh, D., 1983c, Coronavirus IBV: Structural characterisation of the spike protein, $J$. Gen. Virol. 64:2577.

Cavanagh, D., and Davis, P. J., 1986, Coronavirus IBV: Removal of spike glycoprotein S1 by urea abolishes infectivity and haemagglutination but not attachment to cells, J. Gen. Virol. 67:1443.

Cavanagh, D., and Davis, P. J., 1987, Coronavirus IBV: Relationships among recent European isolates studied by limited proteolysis of the virion glycopolypeptides, Avian Pathol. 16:1.

Cavanagh, D., and Davis, P. J., 1992. Sequence analysis of strains of avian infectious bronchitis coronavirus isolated during the 1960s in the UK, Arch. Virol. 130:471.

Cavanagh, D., Darbyshire, J. H., Davis, P. J., and Peters, R. W., 1984, Induction of humoral neutralising and haemagglutination-inhibiting antibody by the spike protein of avian infectious bronchitis virus, Avian Pathol. 13:573.

Cavanagh, D., Davis, P. J., and Pappin, D. J. C., 1986a, Coronavirus IBV glycopolypeptides: Locational studies using proteases and saponin, a membrane permeabilizer, Virus Res. 4:145.

Cavanagh, D., Davis, P. J., Pappin, D. J. C., Binns, M. M., Boursnell, M. E. G., and Brown, T. D. K., 1986b, Coronavirus IBV: Partial amino terminal sequencing of spike polypeptide S2 identifies the sequence Arg-Arg-Phe-Arg-Arg at the cleavage site of the spike precursor propolypeptide of IBV strains Beaudette and M41, Virus Res. 4:133.

Cavanagh, D., Davis, P. J., Darbyshire, J. H., and Peters, R. W., 1986c, Coronavirus IBV: Virus retaining spike glycopolypeptide $\mathrm{S} 2$ but not $\mathrm{S} 1$ is unable to induce virus-neutralizing or haemagglutination-inhibiting antibody or induce chicken tracheal protection, I. Gen. Virol. 67:1435.

Cavanagh, D., Davis, P. J., and Mockett, A. P. A., 1988, Amino acids within hypervariable region 1 of 
avian coronavirus IBV (Massachusetts serotype) spike glycoprotein are associated with neutralization epitopes, Virus Res. 11:141.

Cavanagh, D., Davis, P. J., and Cook, J. K. A., 1992a, Infectious bronchitis virus: Evidence for recombination within the Massachusetts serotype, Avian Pathol. 21:401.

Cavanagh, D., Davis, P. J., Cook, J. K. A., Li, D., Kant, A., and Koch, G., 1992b, Location of the amino acid differences in the $\mathrm{S} 1$ spike glycprotein subunit of closely related serotypes of infectious bronchitis virus, Avian Pathol. 21:33.

Chasey, D., and Alexander, D. J., 1976, Morphogenesis of avian infectious bronchitis virus in primary chick kidney cells, Arch. Virol. 52:101.

Collins, A. R., Knobler, R. L., Powell, H., and Buchmeier, M. J., 1982, Monoclonal antibodies to murine hepatitis virus-4 (strain JHM) define the viral glycoprotein responsible for attachment and cell-cell fusion, Virology 119:358.

Correa, I., Jimenez, G., Sune, C., Bullido, M. J., and Enjuanes, L., 1988, Antigenic structure of the E2 glycoprotein from transmissible gastroenteritis coronavirus, Virus Res. 10:77.

Correa, I., Gebauer, F., Bullido, M. J., Suñé, C., Baay, M. F. D., Zwaagstra, K. A., Posthumus, W. P. A., Lenstra, J. A., and Enjuanes, L., 1990, Localization of antigenic sites of the E2 glycoprotein of transmissible gastroenteritis coronavirus, J. Gen. Virol. 71:271.

Cyr-Coats, K. ST., Storz, J., Hussain, K. A., and Schnorr, K. L., 1988, Structural proteins of bovine coronavirus strain L9: Effects of the host cell and trypsin treatment, Arch. Virol. 103:35.

Dalziel, R. G., Lampert, P. W., Talbot, P. J., and Buchmeier, M. J., 1986, Site-specific alteration of murine hepatitis virus type 4 peplomer glycoprotein E2 results in reduced neurovirulence, $J$. Virol. 59:463.

Daniel, C., and Talbot, P. J., 1990, Protection of mice from lethal coronavirus MHV-A59 infection by monoclonal affinity-purified spike glycoprotein, in: Coronaviruses and Their Diseases (D. Cavanagh and T. D. K. Brown, eds.), pp. 205-210. Plenum Press, New York.

Daniel, C., Anderson, R., Buchmeier, M. J., Fleming, J. O., Spaan, W. J. M., Wege, H., and Talbot, P. J., 1993, Identification of an immunodominant linear neutralization domain on the S2 portion of the murine coronavirus spike glycoprotein and evidence that it forms part of a complex tridimensional structure, J. Virol. 67:1185.

Davies, H. A., and Macnaughton, M. R., 1979, Comparison of the morphology of three coronaviruses, Arch. Virol. 59:25.

Daya, M., Cervin, M., and Anderson, R., 1988, Cholesterol enhances mouse hepatitis virusmediated cell fusion, Virology 163:276.

Dea, S., Garzon, S., and Tijssen, P., 1989a, Identification and location of the structural glycoproteins of a tissue culture-adapted turkey enteric coronavirus, Arch. Virol. 106:221.

Dea, S., Garzon, S., and Tijssen, P., 1989b, Intracellular synthesis and processing of the structural glycoproteins of turkey enteric coronavirus, Arch. Virol. 106:239.

De Groot, R. J., Maduro, J., Lenstra, J. A., Horzinek, M. C., van der Zeijst, B. A. M., and Spaan, W. J. M., 1987a, cDNA cloning and sequencing analysis of the gene encoding the peplomer protein of feline infectious peritonitis virus, I. Gen. Virol. 68:2639.

De Groot, R. J., Luytjes, W., Horzinek, M. C., van der Zeijst, B. A. M., Spaan, W. J. M., and Lenstra, J. A., 1987b, Evidence for a coiled-coil structure in the spike proteins of coronaviruses, J. Mol. Biol. 196:963.

De Groot, R. J., Van Leen, R. W., Dalderup, M. J. M., Vennema, H., Horzinek, M. C., and Spaan, W. J. M., 1989, Stably expressed FIPV peplomer protein induces cell fusion and elicits neutralizing antibodies in mice, Virology 171:493.

Delmas, B., and Laude, H., 1990, Assembly of coronavirus spike protein into trimers and its role in epitope expression, $J$. Virol. 64:5367.

Delmas, B., and Laude, H., 1991, Carbohydrate-induced conformational changes strongly modulate the antigenicity of coronavirus TGEV glycoproteins S and M, Virus Res. 20:107.

Delmas, B., Gelfi, J., and Laude, H., 1986, Antigenic structure of transmissible gastroenteritis virus. II. Domains in the peplomer glycoprotein, J. Gen. Virol. 67:1405.

Delmas, B., Godet, M., Gelfi, J., Rasschaert, D., and Laude, H., 1990a, Enteric coronavirus TGEV: Mapping of four major antigenic determinants in the amino half of peplomer protein E2, in: Coronaviruses and Their Diseases (D. Cavanagh and T. D. K. Brown, eds.), pp. 151-157, Plenum Press, New York. 
Delmas, B., Rasschaert, D., Godet, M., Gelfi, J., and Laude, H., 1990b, Four major antigenic sites of the coronavirus transmissible gastroenteritis virus are located on the amino-terminal half of spike glycoprotein S, J. Gen. Virol. 71:1313.

Deregt, D., and Babiuk, L. A., 1987, Monoclonal antibodies to bovine coronavirus: Characteristics and topographical mapping of neutralising epitopes on the E2 and E3 glycoproteins, Virology 161:410.

Deregt, D., Sabra, M., and Babiuk, L. A., 1987, Structural proteins of bovine coronavirus and their intracellular processing, J. Gen. Virol. 68:2863.

Deregt, D., Parker, M. D., Cox, G. C., and Babiuk, L. A., 1989a, Mapping of neutralizing epitopes to fragments of the bovine coronavirus $\mathrm{E} 2$ protein by proteolysis of antigen-antibody complexes, $J$. Gen. Virol. 70:647.

Deregt, D., Gifford, G. A., Khalidijaz, M., Watts, T. C., Gilchrist, J. E., Haines, D. M., and Babiuk, L. A., 1989b, Monoclonal antibodies to bovine coronavirus glycoproteins E2 and E3: Demonstration of in vivo virus neutralizing activity, J. Gen. Virol. 70:993.

Diego, M. de, Laviada, M. D., Enjuanes, L., and Escribano, J. M., 1992, Epitope specificity of protective lactogenic immunity against swine transmissible gastroenteritis virus, I. Virol. 66: 6502.

Duarte, M., and Laude, H., 1994, Sequence of the spike protein of the coronavirus porcine epidemic diarrhoea virus, J. Gen. Virol. 75:1195.

Egberink, H. F., Ederveen, J., Callebaut, P., and Horzinek, M. C., 1988, Characterization of the structural proteins of porcine epizootic diarrhea virus, strain CV777, Am. J. Vet. Res. 49:1320.

El-Ghorr, A. A., Snodgrass, D. R., Scott, F. M. M., and Campbell, I., 1989, A serological comparison of bovine coronavirus strains, Arch. Virol. 104:241.

Enjuanes, L., Gebauer, F., Correa, I., Bullido, M. J., Sune, C., Smerdon, C., Sanchez, C., Lenstra, J. A., Posthumus, W. P. A., and Meloen, R. H., 1990, Location of antigenic sites of the S-glycoprotein of transmissible gastroenteritis virus and their conservation in coronaviruses, in: Coronaviruses and Their Diseases (D. Cavanagh and T. D. K. Brown, eds.), pp. 159-172, Plenum Press, New York.

Fazakerley, J. K., Parker, S. E., Bloom, F., and Buchmeier, M. J., 1992, The V5A 13.1 envelope glycoprotein deletion mutant of mouse hepatitis virus type- 4 is neuroattenuated by its reduced rate of spread in the central nervous system, Virology 187:178.

Fiscus, S. A., and Teramoto, Y. A., 1987a, Antigenic comparison of feline coronavirus isolates: Evidence for markedly different peplomer glycoproteins, J. Virol. 61:2607.

Fiscus, S. A., and Teramoto, Y. A., 1987b, Functional differences in the peplomer glycoproteins of feline coronavirus isolates, J. Virol. 61:2655.

Frana, M. F., Behnke, J. N., Sturman, L. S., and Holmes, K. V., 1985, Proteolytic cleavage of the E2 glycoprotein of murine coronavirus: Host-dependent differences in proteolytic cleavage and cell fusion, $J$. Virol. 56:912.

Gallagher, T. M., and Buchmeier, M. J., 1990a, Monoclonal antibody-selected variants of MHV-4 contain substitutions and deletions in the E2 spike glycoprotein, in: Coronaviruses and Their Diseases (D. Cavanagh and T. D. K. Brown, eds.), pp. 385-393, Plenum Press, New York.

Gallagher, T. M., Parker, S. E., and Buchmeier, M. J., 1990, Neutralization-resistant variants of a neurotropic coronavirus are generated by deletions within the amino-terminal half of the spike glycoprotein, I. Virol. 64:731.

Gallagher, T. M., Escarmis, C., and Buchmeier, M. J., 1991, Alteration of the pH dependence of coronavirus-induced cell fusion: Effect of mutations in the spike glycoprotein, $J$. Virol. 65:1916.

Garwes, D. J., and Pocock, D. H., 1975, The polypeptide structure of transmissible gastroenteritis virus, J. Gen. Virol. 29:25.

Garwes, D. J., and Reynolds, D. J., 1981, The polypeptide structure of canine coronavirus and its relationship to porcine transmissible gastroenteritis virus, $J$. Gen. Virol. 52:153.

Garwes, D. J., Lucas, M. H., Higgins, D. A., Pike, B. V., and Cartwright, S. F., 1978/79, Antigenicity of structural components from porcine transmissible gastroenteritis virus, Vet. Microbiol. 3:179.

Garwes, D. J., Stewart, F., Cartwright, S. F., and Brown, I., 1988, Differentiation of porcine coronavirus from transmissible gastroenteritis virus, Vet. Rec. 122:86.

Gebauer, F., Posthumus, W. P. A., Correa, I., Suñé, C., Smerdou, C., Sánchez, C. M., Lenstra, J. A., 
Meloen, R. H., and Enjuanes, L., 1991. Residues involved in the antigenic sites of transmissible gastroenteritis coronavirus S glycoprotein, Virology 183:225.

Godet, M., Rasschaert, D., and Laude, H., 1991, Processing and antigenicity of entire and anchor-free spike glycoprotein $\mathrm{S}$ of coronavirus TGEV expressed by recombinant baculovirus, Virology 185:732.

Gombold, J. L., Hingley, S. T., and Weiss, S. R., 1993, Fusion-defective mutants of mouse hepatitis virus A59 contain a mutation in the spike protein cleavage signal, J. Virol. 67:4504.

Grosse, B., and Siddell, S. G., 1994, Single amino acid changes in the S2 subunit of the MHV surface glycoprotein confer resistance to neutralization by S1 subunit-specific monoclonal antibody, Virology 202:814.

Hasony, H. J., and Macnaughton, M. R., 1981, Antigenicity of mouse hepatitis virus strain 3 subcomponents in C57 strain mice, Arch. Virol. 69:33.

Hogue, B. G., and Brian, D. A., 1986, Structural proteins of human respiratory coronavirus OC43, Virus Res. 5:131.

Hogue, B. G., King, B., and Brian, D. A., 1984, Antigenic relationships among proteins of bovine coronavirus, human respiratory coronavirus OC43, and mouse hepatitis coronavirus A59, J. Virol. 51:384.

Hohdatsu, T., Okada, S., and Koyama, H., 1991, Characterization of monoclonal antibodies against feline infectious peritonitis virus type II and antigenic relationship between feline, porcine, and canine coronaviruses, Arch. Virol. 117:85.

Holmes, K. V., Doller, E. W., and Sturman, L. S., 1981, Tunicamycin resistant glycosylation of a coronavirus glycoprotein: demonstration of a novel type of virus glycoprotein, Virology 115:334.

Hopkins, S. R., 1974, Serological comparisons of strains of infectious bronchitis virus using plaquepurified isolants, Avian Dis. 18:231.

Horsburgh, B. C., Brierley, I., and Brown, T. D. K., 1992, Analysis of a 9.6 KB sequence from the 3' end of a canine coronavirus genomic RNA, J. Gen. Virol. 75:2849.

Hussain, K. A., Storz, J., and Kousoulas, K. G., 1991, Comparison of bovine coronavirus (BCV) antigens: Monoclonal antibodies to the spike glycoprotein distinguish between vaccine and wild-type strains, Virology 183:442.

Jacobs, L., de Groote, R., van der Zeijst, B. A. M., Horzinek, M. C., and Spaan, W., 1987, The nucleotide sequence of the peplomer gene of porcine transmissible gastroenteritis virus (TGEV): Comparison with the sequence of the peplomer protein of feline infectious perotonitis virus (FIPV), Virus Res. 8:363.

Jia, W., Karaca, K., Parrish, C. R., and Naqi, S. A., 1993a, Sequences of the spike protein gene of IBV strains Arkansas 99 (Genbank Accession Number L10384) and CV-T2 (Gen Bank Accession Number U047391.

Jia, W., Karaca, K., Naqi, S., Fabricant, J., Bauman, B., and Andriguetto, A., 1993b, Significance of genetic recombination in the evolution of variant IBV in the field, in: Proceedings of the Xth International Congress of the World Veterinary Poultry Association, p. 146, (J. York, ed.), Australian Veterinary Poultry Society, Sydney

Jimenez, G., Correa, I., Melgosa, M. P., Bullido, M. J., and Enjuanes, L., 1986, Critical epitopes in transmissible gastroenteritis virus neutralization, $J$. Virol. 60:131.

Johnson, R. B., and Marquardt, W. W., 1975, The neutralizing characteristics of strains of infectious bronchitis virus as measured by the constant-virus variable-serum method in chicken tracheal cultures, Avian Dis. 19:82.

Jordi, B. J. A. M., Kremers, D. A. W. M., Kusters, H. G., and van der Zeijst, B. A. M., 1989, Nucleotide sequence of the gene coding for the peplomer protein (= spike protein) of infectious bronchitis virus, strain D274, Nucleic Acids Res. 17:6726.

Kant, A., Koch, G., Van Roozelaar, D. J., Kusters, J. G., Poelwijk, F. A. J., and van der Zeijst, B. A. M., 1992, Location of antigenic sites defined by neutralizing monoclonal antibodies on the S1 avian infectious bronchitis virus glycopeptide, J. Gen. Virol. 73:591.

Karaca, K., Naqi, S., and Gelb, J., 1992, Production and characterization of monoclonal antibodies to three infectious bronchitis virus serotypes, Avian Dis. 36:903.

Keck, J. G., Soe, L. H., Makino, S., Stohlman, S. S., and Lai, M. M. C., 1988, RNA recombination of 
murine coronavirus: Recombination between fusion-positive mouse hepatitis virus A59 and fusion-negative mouse hepatitis virus 2, J. Virol. 62:1989.

Kemp, M. C., Hierholzer, J. C., Harrison, A., and Burks, J. S., 1984, Characterisation of viral proteins synthesized in 299E infected cells and effect(s) of inhibition of glycosylation and glycoprotein transport, Adv. Exp. Med. Biol. 173:65.

King, D. J., and Cavanagh, D., 1991, Infectious Bronchitis, in: Diseases of Poultry (B. W. Calnek, H. J. Barnes, C. W. Beard, W. M. Reid, and H. W. Yoder, Jr., eds.), pp 471-484, Iowa State University Press, Ames.

Koch, G., and Kant, A., 1990a, Binding of antibodies that strongly neutralize infectious bronchitis virus is dependent on the glycosylation of the viral peplomer protein, in: Coronaviruses and Their Diseases (D. Cavanagh and T. D. K. Brown, eds.), pp. 143-150, Plenum Press, New York.

Koch, G., and Kant, A., 1990b, Nucleotide and amino acid sequence of the S1 subunit of the spike glycoprotein of avian infectious bronchitis virus strain D3896, Nucleic Acids Res. 18:3063.

Koch, G., Hartog, L., Kant, A., and Van Roozelaar, D. J., 1990, Antigenic domains on the peplomer protein of avian infectious bronchitis virus: Correlation with biological functions, J. Gen. Virol. 71:1929.

Kooi, C., Mizzen, L, Alderson, C., Daya, M., and Anderson, R., 1988, Early events of importance in determining host cell permissiveness to mouse hepatitis virus infection, J. Gen. Virol. 69:1125.

Kooi, C., Cervin, M., and Anderson, R., 1991, Differentiation of acid pH-dependent and nondependent entry pathways for mouse hepatitis virus, Virology 180:108.

Koolen, M. J. M., Borst, M. A. J., Horzinek, M. C., and Spaan, W. J. M., 1990, Immunogenic peptide comprising a mouse hepatitis virus A59 B-cell epitope and an influenza virus T-cell epitope protects against lethal infection, $J$. Virol. 64:6270.

Kryzstyniak, K., and Dupuy, J. M., 1984, Entry of mouse hepatitis virus 3 into cells, J. Gen. Virol. 65:227.

Kubo, H., and Taguchi, F., 1993, Expression of the S1 and S2 subunits of murine coronavirus JHMV spike protein by a vaccinia virus transient expression system, J. Gen. Virol. 74:2373.

Kubo, H., Takase-Yoden, S., and Taguchi, F., 1993, Neutralization and fusion inhibition activities of monoclonal antibodies specific for the $\mathrm{S} 1$ subunit of the spike protein of neurovirulent murine coronavirus JHMV c1-2 variant, J. Gen. Virol. 74:1421.

Künkel, F., and Herrler, G., 1993, Structural and functional analysis of the surface protein of human coronavirus OC43, Virology 195:195.

Kusters, J. G., Niesters, H. G. M., Lenstra, J. A., Horzinek, M. C., and van der Zeijst, B. A. M., 1989a, Phylogeny of antigenic variants of avian coronavirus IBV, Virology 169:217.

Kusters, J. G., Jager, E. J., Lenstra, J. A., Koch, G., Posthumus, W. P. A., Meloen, R. H., and van der Zeijst, B. A. M., 1989b, Analysis of an immunodominant region of infectious bronchitis virus, $J$. Immunol. 143:2692.

Kusters, J. G., Jager, E. J., Niesters, H. G. M., and van der Zeijst, B. A. M., 1990, Sequence evidence for RNA recombination in field isolates of avian coronavirus infectious bronchitis virus, Vaccine 8:605.

Kwon, H., and Jackwood, M., 1993, Sequence of the spike S1 subunit gene of IBV strain JMK (Gen Bank Accession Number L14070) and Gray (Acc. No. L14069).

La Monica, N., Banner, L. R., Morris, V. L., and Lai, M. M. C., 1991, Localization of extensive deletions in the structural genes of two neurotropic variants of murine coronavirus JHM, Virology 182:883.

Laviada, M. D., Videgain, S. P., Moreno, L., Alonso, F., Enjuanes, L., and Escribano, J. M., 1990, Expression of swine transmissible gastroenteritis virus envelope antigens on the surface of infected cells: Epitopes externally exposed, Virus Res. 16:247.

Lenstra, J. A., Kusters, J. G., Koch, G., Van Der Jeijst, B. A. M., 1989, Antigenicity of the peplomer protein of infectious bronchitis virus, Molecular Immunology 1:7.

Li, D., and Cavanagh, D., 1990, Role of $\mathrm{pH}$ in syncytium induction and genome uncoating of avian infectious bronchitis coronavirus (IBV), in: Coronaviruses and Their Diseases (D. Cavanagh and T. D. K. Brown, eds.|, pp. 33-36, Plenum Press, New York.

Li, D., and Cavanagh, D., 1992, Coronavirus IBV-induced membrane fusion occurs at near neutral $\mathrm{pH}$, Arch. Virol. 122:307.

Luytjes, W., Sturman, L. S., Bredenbeek, P. J., Charite, J., van der Zeijst, B. A. M., Horzinek, M. C., 
and Spaan, W. J. M., 1987, Primary structure of the glycoprotein E2 of coronavirus MHV-A59 and identification of the trypsin cleavage site, Virology 161:479.

Luytjes, W., Geerts, D., Posthumus, W., Meloen, E., and Spaan, W., 1989, Amino acid sequence of a conserved neutralising epitope of murine coronaviruses, J. Virol. 63:1408.

Martin, J. P., Chen, W., Obert, G., and Koehren, F., 1990, Characterization of attenuated mutants of MHV3: Importance of the E2 protein in organ tropism and infection of isolated liver cells, in: Coronaviruses and Their Diseases (D. Cavanagh and T. D. K. Brown, eds.), pp. 403-410, Plenum Press, New York.

Matsubara, Y., Watanabe, R., and Taguchi, F., 1991, Neurovirulence of six different murine coronavirus JHMV variants for rats, Virus Res. 20:45.

Michaud, L., and Dea, S., 1993, Characterization of monoclonal antibodies to bovine enteric coronavirus and antigenic variability among Quebec isolates, Arch. Virol. 131:455.

Mizzen, L., Hilton, A., Cheley, S., and Anderson, R., 1985, Attenuation of murine coronavirus infection by ammonium chloride, Virology 142:378.

Mockett, A. P. A., 1985, Envelope proteins of avian infectious bronchitis virus: Purification and biological properties, $J$. Virol. Methods 12:271.

Mockett, A. P. A., Cavanagh, D., and Brown, T. D. K., 1984, Monoclonal antibodies to the S1 spike and membrane proteins of avian infectious bronchitis coronavirus strain Massachusetts M41, $J$. Gen. Virol. 65:2281.

Morris, V. L., Tieszer, C., Mackinnon, J., and Percy, D., 1989, Characterisation of coronavirus JHM variants isolated from Wistar Furth rats with a viral-induced demyelinating disease, Virology 169:127.

Morris, V. L., Wilson, G. A. R., Mckenzie, C. E., Tieszer, C., La Monica, M., Banner, L., Percy, D., Lai, M. M. C., and Dales, S., 1990, Murine hepatitis virus JHM variants isolated from Wistar Furth rats with viral-induced neurological disease, in: Coronaviruses and Their Diseases (D. Cavanagh and T. D. K. Brown, eds.), pp. 411-416, Plenum Press, New York.

Mounir, S., and Talbot, P. J., 1993, Molecular characterization of the S protein gene of human coronavirus OC43, J. Gen. Virol. 74:1981.

Nakanaga, K., Yamanouchi, K., and Fujiwara, K., 1986, Protective effect of monoclonal antibodies on lethal mouse hepatitis virus infection in mice, J. Virol. 59:165.

Niesters, H. G. M., Lenstra, J. A., Spaan, W. J. M., Zijderveld, A. J., Bleumink-Pluym, N. M. C., Hong, F., Van Scharrenburg, G. J. M., Horzinek, M. C., and van der Zeijst, B. A. M., 1986, The peplomer protein sequence of the M41 strain of coronavirus IBV and its comparison with Beaudette strains, Virus Res. 5:253.

Noda, M., Yamashita, H., Koide, F., Kadoi, K., Omori, T., Asagi, M., and Inaba, Y., 1987, Hemagglutination with transmissible gastroenteritis virus, Arch. Virol. 96:109.

Noda, M., Koide, F., Asagi, M., and Inaba, Y., 1988, Physicochemical properties of transmissible gastroenteritis virus hemagglutinin, Arch. Virol. 99:163.

Oleszak, E. L., and Leibowitz, J. L., 1990, Fc receptor-like activity of mouse hepatitis virus E2 glycoprotein, in: Coronaviruses and Their Diseases (D. Cavanagh and T. D. K. Brown, eds.), pp. 51-58, Plenum Press, New York.

Oleszak, E. L., Perlman, S., and Leibowitz, J. L., 1992, MHV S peplomer protein expressed by a recombinant vaccinia virus vector exhibits IgG Fc-receptor activity, Virology 186:122.

Opstelten, D-J E., de. Groote, P., Horzinek, M. C., Vennema, H., and Rottier, P. J. M., 1993, Disulfide bonds in folding and transport of mouse hepatitis coronavirus glycoproteins, J. Virol. 67:7394.

Parker, S. E., Gallagher, T. M., and Buchmeier, M. J., 1989, Sequence analysis reveals extensive polymorphism and evidence of deletions within the E2 glycoprotein gene of several strains of murine hepatitis virus, Virology 173:664.

Parker, M. D., Yoo, D., Cox, G. J., and Babiuk, L. A., 1990, Primary structure of the S peplomer gene of bovine coronavirus and surface expression in insect cells, J. Gen. Virol. 71:263.

Parr, R. L., and Collisson, E. W., 1993, Epitopes on the spike protein of a nephropathogenic strain in infectious bronchitis virus, Arch. Virol. 133:369.

Patterson, S., and Bingham, R. W., 1976, Electron microscope observations on the entry of avian infectious bronchitis virus into susceptible cells, Arch. Virol. 52:191.

Payne, H. R., and Storz, J., 1988, Analysis of cell fusion induced by bovine coronavirus infection, Arch. Virol. 103:27. 
Payne, H. R., Storz, J., and Henk, W. G., 1990, Initial events in bovine coronavirus infection: analysis through immunogold probes and lysosomotropic inhibitors, Arch. Virol. 114:175.

Pfleiderer, M., Routledge, E., and Siddell, S. G., 1990, Functional analysis of the coronavirus MHVJHM surface glycoproteins in vaccinia virus recombinants, in: Coronaviruses and Their Diseases (D. Cavanagh and T. D. K. Brown, eds.), pp. 21-31, Plenum Press, New York.

Posthumus, W. P. A., Meloen, R. H., Enjuanes, L., Correa, I., Van Nieuwstadt, A. P., Kock, G., de Groot, R. J., Kusters, J. G., Luytjes, W., Spaan, W. J., van der Zeijst, B. A. M., and Lenstra, J. A., 1990a, Linear neutralizing epitopes on the peplomer protein of coronavirus, in: Coronaviruses and Their Diseases (D. Cavanagh and T. D. K. Brown, eds.), pp. 181-188, Plenum Press, New York.

Posthumus, W. P. A., Lenstra, J. A., Schaaper, W. M. M., Van Nieuwstadt, A. P., Enjuanes, L., and Meloen, R. H., 1990b, Analysis and simulation of a neutralising epitope of transmissible gastroenteritis virus, I. Virol. 64:3304.

Posthumus, W. P. A., Lenstra, J. A., Van Nieuwstadt, A. P., Schaaper, W. M. M., van der Zeijst, B. A. M., and Meloen, R. H., 1991, Immunogenicity of peptides simulating a neutralization epitope of transmissible gastroenteritis virus, Virology 182:371.

Pulford, D. J., and Britton, P., 1991, Intracellular processing of the porcine coronavirus transmissible gastroenteritis virus spike protein expressed by recombinant vaccinia virus, Virology 182:765.

Raabe, T., Schelle-Prinz, B., and Siddell, S. G., 1990, Nucleotide sequence of the gene encoding the spike glycoprotein of human coronavirus HCV-229E, J. Gen. Virol. 71:1065.

Rasschaert, D., and Laude, H., 1987, The predicted primary structure of the peplomer protein E2 of the porcine coronavirus transmissible gastroenteritis virus, I. Gen. Virol. 68:1883.

Rasschaert, D., Duarte, M., and Laude, H., 1990, Porcine respiratory coronavirus differs from transmissible gastroenteritis virus by a few genomic deletions, J. Gen. Virol. 71:2599.

Roos, D. S., Duchala, C. S., Stephensen, C. B., Holmes, K. V., and Choppin, P. W., 1990, Control of virus-induced cell fusion by host cell lipid composition, Virology 175:345.

Rottier, P. J. M., Horzinek, M. C., and van der Zeijst, B. A. M., 1981, Viral protein synthesis in mouse hepatitis virus strain A59 infected cells: Effect of tunicamycin, J. Virol. 40:350.

Routledge, E., Stauber, R., Pfleiderer, M., and Siddell, S. G., 1991, Analysis of murine coronavirus surface glycoprotein functions by using monoclonal antibodies, $J$. Virol. 65:254.

Sanchez, C. M., Jimenez, G., Laviada, M. D., Correa, I., Sune, C., Bullido, M. J., Gebauer, F., Smerdou, C., Callebaut, P., Escribano, J. M., and Enjuanes, L., 1990, Antigenic homology among coronaviruses related to transmissible gastroenteritis virus, Virology 175:410.

Sawicki, S. G., 1987, Characterisation of a small plaque mutant of the A59 strain of mouse hepatitis virus defective in cell fusion, $A d v$. Exp. Med. Biol. 218:169.

Sawicki, S. G., and Sawicki, D. L., 1986, Coronavirus minus-strand RNA synthesis and effect of cycloheximide on coronavirus RNA synthesis, J. Virol. 57:328.

Schmidt, I., Skinner, M., and Siddell, S., 1987, Nucleotide sequence of the gene encoding the surface projection glycoprotein of coronavirus MHV-JHM, J. Gen. Virol. 68:47.

Schmidt, M. F. G., 1982, Acylation of viral spike glycoproteins: A feature of enveloped RNA viruses, Virology 116:327.

Schmidt, O. W., and Kenny, G. E., 1982, Polypeptides and functions of antigens from human coronaviruses 229E and OC43, Infect. Immun. 35:515.

Schultze, B., Hess, R. G., Rott, R., Klenk, H. D., and Herrler, G., 1990, Isolation and characterization of the acetylesterase of hemagglutinating encephalomyelitis virus (HEV), in: Coronaviruses and Their Diseases (D. Cavanagh and T. D. K. Brown, eds.), pp. 109-113, Plenum Press, New York.

Schultze, B., Gross, H-J., Brossmer, R., and Herrler, G., 1991, The S protein of bovine coronavirus is a hemagglutinin recognizing $9-\mathrm{O}$-acetylated sialic acid as a receptor determinant, J. Virol. 65:6232.

Schultze, B., Cavanagh, D., and Herrler, G., 1992. Neuraminidase treatment of avian infectious bronchitis coronavirus reveals a hemagglutinating activity that is dependent on sialic acidcontaining receptors on erythrocytes, Virology 189:792.

Siddell, S. G., 1982, Coronavirus JHM: Tryptic peptide fingerprinting of virion proteins and intracellular polypeptides, J. Gen. Virol. 62:259.

Siddell, S. G., Wege, H., and Ter Meulen, V. T., 1983, The biology of coronaviruses, J. Gen. Virol. 64:761. 
Simkins, R. A., Saif, L. J., and Weilnau, P. A., 1989, Epitope mapping and the detections of transmissible gastroenteritis viral proteins in cell culture using biotinylated monoclonal antibodies in a fixed-cell ELISA, Arch. Virol. 107:179.

Simkins, R. A., Weilnau, P. A., Bias, J., and Saif, L. J., 1992, Antigenic variation among transmissible gastroenteritis virus (TGEV) and porcine respiratory coronavirus strains detected with monoclonal antibodies to the $\mathrm{S}$ protein of TGEV, Am. J. Vet. Res. 53:1253.

Spaan, W., Cavanagh, D., and Horzinek, M. C., 1990, Coronaviruses, in: Immunochemistry of Viruses II (M. H. V. van Regenmortel and T. D. K. Brown, eds.), pp. 359-380, Elsevier, Amsterdam.

Stauber, R., Pfleiderer, M., and Siddell, S., 1993, Proteolytic cleavage of the murine coronavirus surface glycoprotein is not required for fusion activity, J. Gen. Virol. 74:183.

Stern, D. F., and Sefton, B. M., 1982a, Coronavirus proteins: Biogenesis of avian infectious bronchitis virus virion proteins, J. Virol. 44:794.

Stern, D. F., and Sefton, B. M., 1982b, Coronavirus proteins: Structure and function of the oligosaccharides of the avian infectious bronchitis virus glycoproteins, $J$. Virol. 44:804.

Storz, J., Rott, R., and Kaluza, G., 1981, Enhancement of plaque formation and cell fusion of an enteropathogenic coronavirus by trypsin treatment, Infect. Immun. 31:1214.

Stuhler, A., Wege, H., and Siddell, S. G., 1991, Localization of antigenic sites on the surface glycoprotein of mouse hepatitis virus, J. Gen. Virol. 72:1655.

Sturman, L. S., Holmes, K. V., and Behnke, J., 1980, Isolation of coronavirus envelope glycoproteins and interaction with the viral nucleocapsid, J. Virol. 33:449.

Sturman, L. S., Ricard, C. S., and Holmes, K. V., 1985, Proteolytic cleavage of the E2 glycoprotein of murine coronavirus: Activation of cell-fusing activity of virions by trypsin and separation of two different 90K cleavage fragments, $I$. Virol. 56:904.

Sturman, L. S., Ricard, C. S., and Holmes, K. V., 1990, Conformational change of the coronavirus peplomer glycoprotein at $\mathrm{pH} 8.0$ and $37^{\circ} \mathrm{C}$ correlates with virus aggregation and virus-induced cell fusion, J. Virol. 64:3042.

Sutou, S., Sato, S., Okabe, T., Nakai, M., and Sasaki, N., 1988, Cloning and sequencing of genes encoding structural proteins of avian infectious bronchitis virus, Virology 65:589.

Taguchi, F., 1993, Fusion formation by the uncleaved spike protein of murine coronavirus JHMV variant c1-2, J. Virol. 67:1195.

Taguchi, F., and Fleming, J. O., 1989, Comparison of six different murine coronavirus JHM variants by monoclonal antibodies against the E2 glycoprotein, Virology. 169:233.

Taguchi, F., Siddell, S. G., Wege, H., and Ter Meulen, V., 1985, Characterisation of a variant virus selected in rat brains after infection by coronavirus mouse hepatitis virus JHM, J. Virol. 54:429.

Taguchi, F., Yoden, S., Siddell, S., and Kikuchi, T., 1990, Expression of spike protein of murine coronavirus JHM using baculovirus vector, in: Coronaviruses and Their Diseases (D. Cavanagh and T. D. K. Brown, eds.l, pp. 211-216, Plenum Press, New York.

Taguchi, F., Ikeda, T., and Shida, H., 1992, Molecular cloning and expression of a spike protein of neurovirulent murine coronavirus JHMV variant cl-2, J. Gen. Virol. 73:1065.

Takase-Yoden, S., Kikuchi, T., Siddell, S. G., and Taguchi, F., 1990, Localization of major neutralizing epitopes on the $\mathrm{S} 1$ polypeptide of the murine coronavirus peplomer glycoprotein, Virus Res. 18:99.

Talbot, P. J., and Buchmeier, M., 1985, Antigenic variation among murine coronaviruses: Evidence for polymorphism on the peplomer glycoprotein E2, Virus Res. 2:317.

Talbot, P. J., Salmi, A. A., Knobler, R. L., and Buchmeier, M. J., 1984, Topographical mapping of epitopes on the glycoproteins of murine hepatitis virus-4 (strain JHM): Correlation with biological activities, Virology 132:250.

Talbot, P. J., Dionne, G., and Lacroix, M., 1988, Vaccination against lethal coronavirus-induced encephalitis with a synthetic decapeptide homologous to a domain in the predicted peplomer stalk, I. Virol. 62:3032.

Tijssen, P., Verbeek, A. J., and Dea, S., 1990, Evidence of close relatedness between turkey and bovine coronaviruses, in: Coronaviruses and Their Diseases (D. Cavanagh and T. D. K. Brown, eds.), pp. 457-460, Plenum Press, New York.

Tomley, F. M., Mockett, A. P. A., Boursnell, M. E. G., Binns, M. M., Cook, J. K. A., Brown, T. D. K., and Smith, G. L., 1987, Expression of the infectious bronchitis virus spike protein by recombi- 
nant vaccinia virus and induction of neutralizing antibodies in vaccinated mice, J. Gen. Virol. 68:2291.

van Berlo, M. F., van den Brink, W. J., Horzinek, M. C., and van der Zeijst, B. A. M., 1987, Fatty acid acylation of viral proteins in murine hepatitis virus-infected cells, Arch. Virol. 95:123.

Van Dinter, S., and Flintoff, W. F., 1987, Rat glial C6 cells are defective in murine coronavirus internalization, J. Gen. Virol. 68:1677.

Vautherot, J. F., Madelaine, M. F., and Laporte, J., 1990, Topological and functional analysis of epitopes on the S(E2) and the HE(E3) glycoproteins of bovine enteric coronavirus, in: Coronaviruses and Their Diseases (D. Cavanagh and T. D. K. Brown, eds.), pp. 173-180, Plenum Press, New York.

Vautherot, J-F., Madelaine, M-F., Boireau, P., and Laporte, J., 1992a, Bovine coronavirus peplomer glycoproteins: Detailed antigenic analyses of S1, S2 and HE, J. Gen. Virol. 73:1725.

Vautherot, J-F., Laporte, J., and Boireau, P., 1992b, Bovine coronavirus S glycoprotein: Localisation of an immunodominant region at the amino-terminal end of S2, I. Gen. Virol. 73:3289.

Vennema, H., de Groot, R. J., Harbour, D. A., Dalderup, M., Gruffydd-Jones, T., Horzinek, M. C., and Spaan, W. J. M., 1990a, Immunogenicity of recombinant feline infectious peritonitis virus spike protein in mice and kittens, in: Coronaviruses and Their Diseases (D. Cavanagh and T. D. K. Brown, eds.), pp. 217-222, Plenum Press, New York.

Vennema, H., Rottier, P. J. M., Heijnen, L., Godeke, G. J., Horzinek, M. C., and Spaan, W. J. M., 1990b, Biosynthesis and function of the coronavirus spike protein, in: Coronaviruses and Their Diseases (D. Cavanagh and T. D. K. Brown, eds.), pp. 9-19, Plenum Press, New York.

Vennema, H., Heijnen, L., Zijderfeld, A., Horzinek, M. C., and Spaan, W. J. M., 1990c, Intracellular transport of recombinant coronavirus spike proteins: Implications for virus assembly, $J$. Virol. 64:339.

Vennema, H., de Groot, R. J., Harbour, D. A., Dalderup, M., Gruffydd-Jones, T., Horzinek, M. C., and Spaan, W. J. M., 1990d, Early death after feline infectious peritonitis virus challenge due to a recombinant vaccinia virus immunization, $J$. Virol. 64:1407.

Wang, L., Junker, D., Hock, L., Ebiary, E., and Collisson, W. W., 1994, Evolutionary implications of genetic variations in the $\mathrm{S} 1$ gene of infectious bronchitis virus, Virus Res. 34:327.

Wang, F-I., Fleming, J. O., and Lai, M. M. C., 1992, Sequence analysis of the spike protein gene of murine coronavirus variants: Study of genetic sites affecting neuropathogenicity, Virology 186:742.

Wang, L., Junker, D., and Collisson, E. W., 1993, Evidence of natural recombination within the S1 gene of infectious bronchitis virus, Virology 192:710.

Wege, H., Dorries, R., and Wege, H., 1984, Hybridoma antibodies to the murine coronavirus JHM: Characterisation of epitopes on the peplomer protein, J. Gen. Virol. 65:1931.

Weismuller, D. G., Sturman, L. S., Buchmeier, M. J., Fleming, J. O., and Holmes, K. V., 1990, Monoclonal antibodies to the peplomer glycoprotein of coronavirus mouse hepatitis virus identify two subunits and detect a conformational change in the subunit released under mild alkaline conditions, $J$. Virol. 64:3051.

Welch, S-K. W., and Saif, L. J., 1988, Monoclonal antibodies to a virulent strain of transmissible gastroenteritis virus: Comparison of reactivity with virulent and attenuated virus, Arch. Virol. 101:221.

Wesley, R. D., 1990, Nucleotide sequence of the E2-peplomer protein gene and partial nucleotide sequence of the upstream polymerase gene of transmissible gastroenteritis virus (Miller strain), in: Coronaviruses and Their Diseases (D. Cavanagh and T. D. K. Brown, eds.), pp. 301-306, Plenum Press, New York.

Wesley, R. D., Woods, R. D., and Cheung, A. K., 1991, Genetic analysis of porcine respiratory coronavirus, an attenuated variant of transmissible gastroenteritis virus, J. Virol. 65:3369.

Wesseling, J. G., Godeke, G-J., Schijns, V. E. C. J., Prevec, L., Graham, F. L., Horzinek, M. C., and Rottier, P. J. M., 1993, Mouse hepatitis virus spike and nucleocapsid proteins expressed by adenovirus vectors protect mice against a lethal infection, J. Gen. Virol. 74:2061.

Wesseling, J. G., Vennema, H., Godeke, G-I., Horzinek, M. C., Spaan, W. J. M., and Rottier, P. J. M., 1994, Nucleotide sequence and expression of the spike (S) gene of canine coronavirus and comparison with the S proteins of feline and porcine coronaviruses, J. Gen. Virol. 75:1789.

Wilson, I. A., Skehel, J. J., and Wiley, D. C., 1981, Structure of the haemagglutinin membrane glycoprotein of influenza virus at 3 A resolution, Nature 289:366. 
Wysocka, M., Korngold, R., Yewdell, J., and Bennink, J., 1989, Target and effector cell fusion accounts for B lymphocyte-mediated lysis of mouse hepatitis virus-infected cells, I. Gen. Virol. 70:1465.

Yoo, D., Parker, M. D., and Babiuk, L. A., 1990, Analysis of the S spike (peplomer) glycoprotein of bovine coronavirus synthesized in insect cells, Virology 179:121.

Yoo, D., Parker, M. D., and Babiuk, L. A., 1991a, the S2 subunit of the spike glycoprotein of bovine coronavirus mediates membrane fusion in insect cells, Virology 180:395.

Yoo, D., Parker, M. D., Song, J., Cox, G. J., Deregt, D., and Babiuk, L. A., 1991b, Structural analysis of the conformational domains involved in neutralization of bovine coronavirus using deletion mutants of the spike glycoprotein S1 subunit expressed by recombinant baculoviruses, Virology 183:91.

Zhang, X., Kousoulas, K. G., and Storz, J., 1991, Comparison of the nucleotide and deduced amino acid sequences of the $\mathrm{S}$ genes specified by virulent and avirulent strains of bovine coronaviruses, Virology 183:397.

Zhang, X., Herbst, W., Kousoulas, K. G., and Storz, J., 1994, Comparison of the S genes and the biological properties of respiratory and enteropathogenic bovine coronaviruses, Arch. Virol. 134:421. 